\title{
A POLUIÇÃO VISUAL E O SEU CONTROLE NO MUNICÍPIO DE CAXIAS DO SUL A PARTIR DA LEI MUNICIPAL № 412/2012
}

\section{VISUAL POLLUTION AND ITS CONTROL IN CAXIAS DO SUL COUNTY FROM THE MUNICIPAL LAW №. 412/2012}

\section{Resumo}

\author{
Barbara Bedin ${ }^{1}$ \\ Magaly Ferrari² \\ Rodrigo Gajardo 3
}

Em uma cidade poluída visualmente, destaca-se a importância da limpeza nas fachadas para o bem-estar dos cidadãos, para manter ou melhorar a sua qualidade de vida. Isso porque os resíduos, os lixões, a fumaça, os agrotóxicos, não são as únicas formas de poluição. Desta forma, objetiva-se, com este estudo, analisar as competências ambientais municipais a partir da Constituição Federal de 1988 e seus princípios ambientais, legislações ambientais nas esferas federal e municipal e, de forma pragmática, a Lei Complementar no 412/12, que disciplina o uso de veículos de divulgação no Município de Caxias do Sul, no qual analisamos o caso concreto de sua aplicabilidade e os resultados obtidos. Quanto ao método deste trabalho, ele foi o dedutivo e, no caso dessa pesquisa, parte-se da lei geral (Constituição Federal) para chegar à legislação muncipal que não pode contrariar a lei maior. A pesquisa se caracteriza por ser exploratória e bibliográfica, cujos dados foram coletados por meio de obras, tais como as doutrinas jurídicas, artigos científicos e legislação. Desta forma, concluídos que é preciso verificar se a população também faz sua parte, auxiliando na fiscalização, sendo esta uma valiosa contribuição para que o meio ambiente fique livre da poluição visual.

Palavras-chave: Meio ambiente. Poluição visual. Lei Complementar no 412/12. Qualidade de vida. Degradação visual.

\begin{abstract}
In a city that is visually polluted, we highlight the importance of cleaning of the external part of the buildings, to keep and improve the quality of life of the citizens. This is because the waste, landfills , smoke, pesticides, are not the only forms of pollution. Thus, the main objective of this final paper is to analyze the environmental competences of the cities, through the Federal Constitutional of 1988 and its environmental principles, as well as the federal and municipal environmental legislations, and, in a pragmatic way, the Supplementary Law 412/12, that regulates the use of the means of publicizing in Caxias do Sul City, in which we analyzed a real case, considering the applicability and the achieved results. The method applied is deductive, that starts from the general law (Constitution) to the municipal legislation that cannot go against the major law. This research is also an exploratory and bibliographical research, which data were collected through legal doctrines, articles and legislation. Therefore, we concluded that it is necessary to verify if the population its part in the process, that is the monitoring of the city, since it is a valuable contribution to make the environment free of the visual pollution.

Keywords: Environment. Visual pollution. Supplementary Law 412/12. Quality of life. Visual degradation.

\footnotetext{
1 Docente do Doutorado em Letras UCS associação ampla UniRitter. Mestre em Direito. E-mail: barbara@prelum.com.br

${ }^{2}$ Doutora em Letras-Linguística - PUCRS (2007).Email: magalyferrari@hotmail.com
}

${ }^{3}$ Aluno de graduação do curso de Direito da FSG. E-mail: rodrigo@prelum.com.br
\end{abstract}




\section{INTRODUÇÃO}

Em uma cidade poluída visualmente, a importância da limpeza nas fachadas para o bemestar dos cidadãos é ponto importante para manter ou melhorar a sua qualidade de vida. Isso, porque o ser humano é integrante do meio ambiente e seu desequilíbrio o afeta diretamente. A partir de Baudrillard (1995, p. 12), verifica-se que o consumo não tem relação com uma fruição pessoal, mas sim, é uma "instituição social coactiva que determina os comportamentos antes mesmo de ser reflectida pela consciência dos actores sociais". Dessa forma, os objetos designam o ser e a categoria social de seu possuidor e a hierarquia social é determinada no padrão de consumo. Sendo assim, a poluição visual, através do excesso de placas; outdoors; letreiros; faixas; back lights; front lihts, painéis eletrônicos ou pintados determinam o comportamento social a ser seguido e suas alterações, por consequência, modificam o comportamento exigido do indivíduo. Esse artigo tem o objetivo de verificar, no que diz respeito à poluição visual, quais os impactos sofridos na paisagem urbana da cidade de Caxias do Sul a partir implementação da Lei Municipal no $412 / 2012$

Ao tratar sobre o tema da poluição, nosso pensamento nos remete aos resíduos produzidos pelas fábricas e lançados em rios, os lixões a céu aberto, a fumaça produzida por automóveis e indústrias, os agrotóxicos pulverizados nas plantações, entre outros, resultando na degradação do meio ambiente e, portanto, afetando a qualidade de vida dos seres humanos, bem como de todo o meio de vida. Para Ivan Carneiro Castanheiro (2009), existem outras formas de poluição que ocasionam consequências danosas à vida, como a sonora e a visual que causam prejuízos à saúde física e psicológica. O autor (CASTANHEIRO, 2009, p. 64) considera que o homem é o único responsável pela poluição visual: "Poluição visual é a desarmonia ou degradação visual geradora de desequilíbrio do meio ambiente artificial [...] é causada pelo próprio homem, o qual insere no meio ambiente elementos de forma desordenada".

A poluição visual indiscutivelmente gera desarmonia, prejudica o bem-estar da população e compromete a sua saúde. Esse desequilíbrio no meio ambiente artificial atinge seus habitantes, com efeitos psicológicos, os quais são difíceis de serem diagnosticados.

Não estando de forma isolada, o excesso de informações, exemplificado através de placas, muitas vezes, com alto grau de luminosidade, vai se unindo a outros elementos da vida da sociedade moderna, como a poluição sonora, a poluição hídrica e o próprio estresse que já tem suas causas na sociedade contemporânea. 
Ivan Coelho Dantas e José Ednaldo Feitoza da Silva (2008), em estudo realizado sobre a poluição visual e os seus malefícios, realizado no município de Campina Grande na Paraíba, concluíram que um dos problemas do descontrole da publicidade visual é a perda da originalidade do meio urbano, através do excesso de outdoors, placas, cartazes, banners, painéis eletrônicos, faixas, tabuletas e luzes. Os prédios e monumentos históricos, por sua vez, perdem a sua importância por ficarem escondidos devido a exposição em excesso dos materiais publicitários. Além disso, outros males foram detectados, principalmente relacionados à saúde de sua população. Entre as pessoas que participaram daquele estudo, foram relatados vários sintomas sofridos, desde mal-estar, cansaço, até dores de cabeça, quando em exposição visual por longos períodos a cores fortes, excesso de letreiros e outras formas de publicidade.

Como bem explica Castanheiro (2009, p. 68), "a atividade econômica sempre produz algum nível de poluição", e, com isso, um certo grau de poluição visual é aceitável, porém seu controle se faz necessário, para assegurar o bem-estar das pessoas. Os interesses comerciais dos empreendedores devem ser compatíveis com o bem-estar da população das cidades. Nesta ótica, as atividades econômicas somente sofrerão sanções quando as suas ações forem nocivas e inconvenientes. Revela ainda Ivan Carneiro Castanheiro (2009, p. 65) que "a saúde psíquica das pessoas em geral guarda alguma relação com a ordenação da paisagem urbana, reflexo da harmonia ou desarmonia visual".

Portanto, em nossa vida cotidiana, há uma carga neurótica que deve ser amenizada. A poluição visual, por sua vez, ultrapassa a estética, refletindo-se na segurança do trânsito e, por conseguinte, na qualidade de vida das pessoas. Para tanto, o controle público no tocante à poluição visual, através de padrões técnicos e legais admissíveis, se fazem necessários. Além dos danos causados a saúde pela poluição visual, outro é o relacionado ao trânsito, no qual a distração, gerada tanto aos motoristas quanto aos pedestres, transforma ruas, avenidas e rodovias em locais de alto potencial de acidentes.

O excesso de informações visuais, a exemplo de outdoors, normalmente não é visto como poluição pelos integrantes da sociedade, principalmente, por se tratar de algo cotidiano. Em especial, o estímulo desenfreado ao consumo acaba sendo o elemento principal nos apelos publicitários, nos centros urbanos e também estendidos aos bairros periféricos. As placas, faixas, outdoors, etc. são a expressão publicitária massiva, sendo aparentemente a regra a seguinte: quanto maior, mais colorido e mais chamativo este apelo, maior será o retorno comercial, 
ignorando-se, por conseguinte, o bem-estar visual da população que habita e circula por esses ambientes.

Não obstante, a publicidade indiscriminada decorre do sistema capitalista que necessita do consumo desenfreado para se manter. Com o crescimento populacional e, consequentemente, o aumento de consumo, o mercado amplia os seus investimentos em propaganda, para atingir o maior número possível de consumidores. Desta maneira, a propaganda, sendo utilizada de forma indiscriminada, pode criar muitos problemas à população, podendo ser de cunho social, com o consumo sem limites ou com a ampliação das horas de trabalho sem renumeração compatível; e na forma ambiental, porque o estímulo ao consumo implica aumento na produção (do objeto a ser consumido), do uso intensivo de recursos naturais (energia, água, entre outros) gera, produção excessiva de poluentes, através da geração de resíduos sólidos, resultado este da atividade publicitária e ainda através do consumo excessivo de energia.

As principais formas de liberação de energia são a energia sonora, gerando a poluição sonora, a energia luminosa e aquela abordada neste trabalho que é a poluição visual, através da produção indiscriminada de publicidade. Portanto, as consequências dessas atividades humanas trazem prejuízos à natureza e aos animais alterando seus hábitos; e se refletem na qualidade de vida do próprio homem, uma vez que a poluição visual aumenta o nível de estresse dos indivíduos. De acordo com Vasconcellos (2003. p. 7) são considerados agentes causadores do estresse o excesso de:

1. Mídia externa: Placas; Outdoors; Letreiros; Faixas; Back Lights; Front Lihts, Painéis eletrônicos ou pintados;

2. Grafites e pichações;

3. Aglomerações permanentes de pessoas em áreas restritas da cidade (ex: zonas de pedestres, calçadões, aeroportos, estações de metrô);

4. Recipientes de lixo expostos abertamente em lugares públicos;

5. Engarrafamentos de trânsito e vias expressas com deslocamento de automóveis e caminhões em alta velocidade;

6. Favelas com deficiente organização urbana e arquitetônica;

7. Moradores de rua alojados em viadutos e praças públicas;

8. Postes de fiação aérea (telefonia, iluminação, tv a cabo).

Estes elementos são causadores de alteração de humor tão significativas que são determinantes para o início de um conjunto de sintomas fisiológicos e psicológicos que poderão 
culminar com o óbito do sujeito. A poluição visual, de acordo com Vasconcellos (2003. p. 6), é um dos mais importantes fatores de distresse ${ }^{4}$ presente no contexto físico-social da vida contemporânea. Isso porque $85 \%$ (oitenta e cinco por cento) das informações do meio ambiente são processadas através do sistema visual, tendo potencial para desencadear um processo de estress dentro do corpo.

Especificamente no que diz respeito a poluição visual, de acordo com Pacheco Fiorillo (2012, p. 342), ela está relacionada ao meio ambiente artifical (conjunto de todo o espaço construído e os espaços habitáveis pelo homem) quando existe:

Qualquer alteração resultante de atividades que causem degradação da qualidade ambiental desses espaços, vindo a prejudicar, direta ou indiretamente, a saúde, a segurança e o bem-estar da população, bem como a criar condições adversas às atividades sociais e econômicas ou a afetar as condições estéticas ou sanitárias do meio ambiente.

A poluição visual, continua Pacheco Fiorillo (2012), normalmente se dá de forma gradativa, acostumando os indivíduos com a desarmonia visual. Além disso, não é toda e qualquer poluição visual que deve ser obstada, somente aquela que interferir de forma nociva ou inconveniente, uma vez que certas categorias econômicas reivindicam o seu exercício. São fontes de poluição visual, de acordo com Maria Santa Martins Timbo (2011): pichações, monumentos malconservados, disposição inadequada do lixo, extensão de redes aéreas e excesso de propagandas das mais diversas naturezas.

Questiona-se, também, sobre a influência em nossas decisões ao consumo, gerada por estímulos, que consciente ou inconscientemente nos motivam a tal procedimento. Os apelos publicitários, em especial os tratados neste estudo, através de placas, fachadas, faixas, banners, entre outros regulados pela Lei Municipal no 412/2012, caracterizam-se por sua potencial motivação, a qual gera uma necessidade que desperta um desejo ao consumo. Segundo estudo aprofundado em sua tese, Eliane Karsaklian (2012) trata da motivação, necessidade e desejo, causados no comportamento do consumidor acerca dos apelos publicitários, o qual, em regra, possui percepção de suas reais necessidades, mas as suas atitudes pendem ao consumo desnecessário. Concluímos, desta forma, através do estudo de Karsaklian (2010, p. 20), que a Lei no 412/2002, inibindo o excesso de apelo publicitário nas fachadas dos comércios localizados no município de Caxias do Sul, estará contribuindo inclusive no consumo consciente da população caxiense:

\footnotetext{
${ }^{4}$ O motivo que causa o stresse é negativo, irritante ou desagradável. (VASCONCELLOS, 2003, p. 2).
} 
O ato de compra não surge do nada. Seu ponto de partida é a motivação, que vai conduzir a uma necessidade, a qual, por sua vez, despertará um desejo. Com base em tal desejo, surgem as preferências por determinadas formas específicas de atender à motivação inicial e essas preferências estarão diretamente relacionadas ao autoconceito: o consumidor tenderá a escolher um produto que corresponda ao conceito que ele tem ou que gostaria de ter de si mesmo. No entanto, e em sentido contrário à motivação, surgem os freios. Trata-se da consciência de risco que vem implícita ou explicitamente relacionada com o produto.

Em meio ao dilema entre a força da motivação e aquela dos freios, impõe-se a personalidade do indivíduo, a qual desembocará no autoconceito.

A reunião de todas essas variáveis resultará numa percepção particular dos produtos, que, por sua vez, desencadeará atitudes positivas ou negativas com relação a eles, o que, naturalmente, terá impacto sobre suas preferências. [Grifo do autor].

As necessidades básicas humanas estabelecem em sua estrutura a busca da satisfação pelo consumo. Através de sua evolução, o ser humano possui necessidades durante toda sua vida. Elas podem ser, conforme sua natureza, sendo necessidades biológicas, os quais são elementos indispensáveis para manutenção da vida, como alimento, água, ar e abrigo ou ainda necessidades de caráter psicológico, que são elementos necessários, para tornar-se membro de uma cultura ou sociedade.

Ainda referente ao consumo, a autora Eliane Karsaklian (2012) exemplifica muito bem uma das formas de cobrança social pelo consumo por determinados produtos. Quando uma determinada pessoa que, por opção ou não, não possuir determinado bem de consumo, estará sujeita a questionamentos e até a uma pressão social para o consumo deste bem. Assim a autora se manifesta (KARSAKLIAN, 2012, p. 37):

Se pensarmos no que ocorria há poucos anos, veremos que a pergunta que se fazia era: "você tem um telefone celular?" Hoje em dia a pergunta tornouse: "Qual o número de seu celular?" Face a isto, a pessoa que não possuir um celular deverá explicar-se, pois será percebida como um ser raro e diferente. Este é o resultado da pressão social.

No sentido inverso aos transtornos gerados pelos meios de poluição visual, este trabalho busca identificar se a Lei $n^{\circ}$ 412/2012 do Município de Caxias do Sul responde aos interesses ambientais, local onde a sociedade participa desta construção. Busca-se identificar se os usuários de veículos de comunicação cumprem a norma e verificar se a população também faz sua parte, auxiliando na fiscalização, para que a implementação desta lei ocorra em todo município e tenhamos um ambiente sem poluição visual. Neste mesmo caminho, o pesquisador considera importante o tema abordado, para que este trabalho possa servir de subsídio para fins acadêmicos, sociais e jurídicos. 
Na primeira parte aborda-se a proteção ambiental no Brasil, analisando a Constituição Federal de 1988 (doravante Constituição) e os seus princípios ambientais, as legislações ambientais federais infraconstitucionais e, por fim, as legislações ambientais municipais.

A segunda parte é reservada para a legislação ambiental no Município de Caxias do Sul, sendo analisados os aspectos ambientais de seu Plano Diretor Municipal e, em especial, a Lei Municipal no 412/2012, que disciplina o uso dos veículos de divulgação no município.

Finalmente, a terceira parte analisa a implementação e os resultados decorrentes da Lei Municipal no 412/2012, com a representação gráfica de um espaço público antes e depois da adaptação à nova legislação.

No que diz respeito ao método deste trabalho, ele será o dedutivo que parte do geral e vai para o particular. Neste trabalho, parte-se da lei geral (Constituição) e vai para uma legislação muncipal que não pode contrariar a lei maior. O procedimento metodológico será a pesquisa exploratória e bibliográfica, cujos dados foram coletados por meio de obras, tais como as doutrinas jurídicas, artigos científicos, da legislação, para verificar como a aplicação da referida lei é realizada em um caso concreto da cidade de Caxias do Sul, a fim de que o tema seja bem compreendido.

\section{A Legislação Ambiental na Constituição Federal Brasileira}

O movimento social ambientalista iniciou no Brasil na década de 1970, explica Behrends (2011), período no qual existiam muitas denúncias, mas sentia-se, mais do que nunca, a necessidade de agir. Consolidava-se a preocupação de que atos imprudentes teríam reflexos negativos na vida das próprias pessoas. O cidadão passa a reivindicar sua participação nas decisões políticas que afetam sua vida futura e a humanidade. Esse movimento vai ao encontro da discussão dos problemas ambientais mundiais feita por diversos países na Conferência de Estocolmo, em junho de 1972. O primeiro resultado do movimento social internacional foi Estocolmo esclarece Behrends (2011). A década de 1980, prossegue Behrends (2011), simboliza a conscientização ecológica, da luta pela democratização. Nesse período, no Brasil, foi criado o Projeto Tamar pelo Instituto Brasileiro de Desenvolvimento Florestal e instituiu-se a Política Nacional do Meio Ambiente, permitindo a responsabilização dos causadores da destruição natural e a cobrança de indenização pelo prejuízo ambiental.

Com a Assembleia Constituinte e a promulgação da Constituição, este começou a ter um tratamento prioritário pelo legislador, no qual o artigo 255 da Constituição Federal trata de diversos princípios constitucionais acerca do tema, como o do desenvolvimento sustentável, o da 
prevenção, o da ubiquidade, entre outros. O Brasil, no ano de $1992^{5}$, seguindo a linha constitucional de priorização de políticas ambientais, transforma a Secretaria do Meio Ambiente da Presidência da República em Ministério do Meio Ambiente.

Neste sentido, bem destaca Weschenfelder (2012), ao dizer que, através da vontade do povo brasileiro, manifestada na Constituição, está expresso, no artigo 225, caput, o princípio do direito ao meio ambiente equilibrado. Registra ainda que a palavra equilíbrio, segundo o Dicionário Houaiss da Língua Portuguesa, tem o significado de "igualdade de força entre duas ou mais coisas ou pessoas, grupos". O autor acima afirma, ainda, que o meio ambiente equilibrado nos dá a ideia não só de natureza, mas também, de todos os elementos que a compõem. Necessário é olhar a natureza, porque nela não apenas o ser humano ${ }^{6}$ habita, como ainda, todas as espécies de vida. Também, em relação ao meio ambiente ecologicamente equilibrado, destaca-se o pensamento de Weschenfelder (2012, p 39) expresso no IX Congresso Nacional do Ministério Público:

O meio ambiente ecologicamente equilibrado deve ser mais que um princípio de Direito Ambiental. Deve ser um dos princípios fundamentais do listado Democrático de Direito, tese que defendemos em 1992, no IX Congresso Nacional do Ministério Público, em Salvador, Bahia, que foi aprovada, por unanimidade, pelo Grupo de Trabalho Temático e pelo Plenário. [grifo do autor].

Como bem lembra ainda Weschenfelder (2012), remetendo-se à Grécia Antiga, o senso, inerente ao significado 'natureza', indiscutivelmente tem a sua origem na constituição espiritual, uma vez que os gregos sempre consideraram as coisas do mundo como fazendo parte de um todo e não, isoladamente. Acreditavam que existia uma conexão viva entre tudo que havia na Terra e faziam ligações entre posição e sentido. Uma concepção orgânica, que interliga as partes, transformando-o em um todo. O autor (WESCHENFELDER, 2012, p. 40) ainda assinala que qualquer alteração na natureza, "como uma seca prolongada ou um inverno mais rigoroso", tem influência

\footnotetext{
${ }^{5}$ Em 1992 realizou-se a $2^{\text {a }}$ Conferência sobre Meio-Ambiente e Desenvolvimento (CNUMAD) no Rio de Janeiro, a criação do Ministério do Meio Ambiente é uma resposta a esta Conferência e do conhecido "Relatório do Nosso Futuro Comum" onde as propostas dos países da periferia do capitalismo não foram contempladas no ideário do desenvolvimento sustentável. Isso evidencia que se mantém intocado a necessidade de debater sobre o modo de produção de mercadorias e se atribui os problemas aos desvios do modelo de cada país e não do modo capitalista de produção que é predador.

${ }^{6} \mathrm{O}$ autor aborda o homem estritamente como um ser biológico, descartando sua especificidade natural de produzir cultura e por isso todos os povos e culturas são e não são naturais, entendimento que não podemos desconsiderar. Buscou-se na natureza o paradigma para a sociedade nos séculos XVIII e XIX em determinadas vertentes do lluminismo, do Racionalismo, por onde o Positivismo sintetiza a natureza como algo objetivo, na qual as leis naturais são livres de paixões, ideologias, subjetividades. Basta aplicar aos homens estas leis objetivas e encontrar a sociedade naturalmente justa. No entanto, a sociedade é em um determinado tempo e espaço representada por seus valores que sofrem constantes transformações, ou seja, é um processo dinâmico, no qual o homem intervém e modifica a natureza.
} 
direta na sobrevivência do ser humano, causando, nestes casos, inclusive a morte pela sede ou pela fome. Se a natureza em sua dinâmica produz seca, os homens a partir de políticas públicas e do desenvolvimento tecnológico podem impedir ou minimizar esses efeitos. Assim é importante entender a complexidade do problema ambiental no âmbito das relações sociais e não naturalizar problemas de natureza diversa.

Importante contribuição de Pacheco Fiorillo (2011) que leciona sobre a definição legal de meio ambiente, através da análise do Direito Ambiental na Constituição Federal de 1988. O autor verifica que existem críticas à terminologia empregada, no que diz respeito ao uso da palavra meio, já que tudo aquilo que nos circunda é relacionado ao meio ambiente. Assim ele explica: "Costumase criticar tal termo, porque pleonástico, redundante, em razão de ambiente já trazer em seu conteúdo a ideia de 'âmbito que circunda', sendo desnecessária a complementação pela palavra meio". (FIORILLO, 2011, p. 72-73). No entanto, destaca que no artigo 225 da Constituição, optou-se por estabelecer dois objetos de proteção ambiental: um é a qualidade do meio ambiente (imediato), e o outro é a proteção da saúde, do bem-estar e a segurança da população (mediato). Dessa forma, Fiorillo (2011, p. 73) conclui que "a definição de meio ambiente é ampla, devendo-se observar que o legislador optou por trazer um conceito jurídico indeterminado, a fim de criar um espaço positivo de incidência da norma. " E esse conceito jurídico indeterminado permite que o entendimento sobre o meio ambiente se 'amolde' os reais interesses e valores defendidos pelos indivíduos integrantes de uma sociedade.

Na legislação infraconstitucional, na Lei da Política Nacional do Meio Ambiente (Lei $n^{\circ}$ 6.938/81), a definição de meio ambiente é verificada no art. $3^{\circ}$, I como sendo "o conjunto de condições, leis, influências e interações de ordem física, química e biológica, que permite, abriga e rege a vida em todas as suas formas" (BRASIL, 1981). Neste sentido, como bem registra Pacheco Fiorillo (2011, p. 72-73), o conceito de meio ambiente, dado pela Lei da Política Nacional do Meio Ambiente, foi recepcionado pela Constituição Federal de 1988. Não só a tutela pelo meio ambiente natural foi tratada na Lei Maior de 1988, mas também, o meio ambiente artificial, o cultural e o do trabalho. A conclusão mencionada tem seu alcance no artigo 225 da Constituição de 1988, quando utiliza a expressão sadia qualidade de vida. Com isso, o legislador amplia o conceito jurídico para o âmbito indeterminado, criando, assim, um espaço positivo na aplicação da norma.

Ainda, a respeito deste ponto, vale registrar que Pacheco Fiorillo (2011, p, 73) considera que os legisladores constituintes estabeleceram dois elementos de proteção ambiental: "um 
imediato, que é a qualidade do meio ambiente, e outro mediato, que é a saúde, o bem-estar e a segurança da população, que se vêm sintetizando na expressão da qualidade de vida".

Vale lembrar que, mesmo antes da Constituição de 1988, já existiam normas regulamentadoras que tratavam das questões do controle da construção e proteção ambiental. A Constituição Federal de 1934 atribuía à União competência legislativa sobre "bens de domínio federal, riquezas do subsolo, mineração, metalurgia, água, energia hidrelétrica, florestas, caça e pesca e sua exploração". (Art. 5, inciso XIX). Já a Constituição de 1937 estabelecia a competência privativa da União, para legislar sobre "os bens de domínio federal, minas, metalurgia, energia hidráulica, águas, florestas, caça e pesca e sua exploração". (Art. 16, inciso XIV). (ANTUNES, 2007, p. 54).

Cabia à administração municipal o controle das construções a partir de um Código de Obras, da aprovação de projetos, do alvará, embargos de obra e da demolição compulsória de obra e sempre atendendo à função social da propriedade, estabelecida no inciso III, do art. 160, da Constituição da República Federativa do Brasil de 1967.

A proteção ambiental, por sua vez, tinha como objetivo obstaculizar a ação destruidora da natureza que foi agravada no século XX, "em razão do desmedido crescimento das populações e do avanço científico e tecnológico, que propiciou à humanidade a mais completa dominação da terra, das águas e do espaço aéreo". (MEIRELLES, 1979, p. 187). Ou seja, para assegurar a sobrevivência das futuras gerações em condições adequadas de alimentação, saúde e bem-estar, o Estado viu a necessidade de preservar o meio ambiente através de formas para impedir o crescimento populacional e o uso da técnica. No entanto, controlar o crescimento populacional e o avanço científico e tecnológico não é a solução. A técnica é apenas um meio concebido para realizar um fim e o crescimento da população problematizado tem suas raízes em Malthus, visão superficial do problema ligado ao controle e domínio da população. De acordo com Alves (2002, p. 21), Malthus considerava a fome, as doenças, a epidemia, as guerras e a miséria como ''freios positivos' necessários para o controle da população e um entrave a qualquer tipo de progresso". Isso porque, se a pobreza fosse combatida, as famílias teriam mais filhos sobreviventes acarretando em uma 'explosão populacional' que não seria acompanhada pelos meios de subsistência.

Para evitar esse crescimento populacional exagerado Malthus criou o salário de subsistência (capaz de sustentar não mais que um casal e dois filhos sobreviventes). No entanto, Alves (2002, p. 21) sustenta que o salário de subsistência não foi criado por Malthus como forma 
de limitar a população, mas sim, o princípio de população foi apresentado para justificar o salário de subsistência:

Como ideólogo conservador e porta-voz declarado dos ricos fazendeiros, ele defendia os ganhos do latifúndio contra os interesses da burguesia nascente e o progresso das classes populares. O modelo econômico/demográfico de Malthus visava a defender a inflexibilidade do salário de subsistência em benefício da renda da terra. Por conseguinte, ele foi contra a liberação do comércio e a importação de cereais, como reivindicavam os setores urbanos da Inglaterra de seu tempo. Essa liberação possibilitaria a redução do preço dos alimentos, barateando o custo de reprodução da força de trabalho, o que beneficiaria o lucro da burguesia industrial e elevaria o poder de compra dos salários. Dessa forma, Malthus defendia o salário de subsistência como forma de equilibrar as taxas de natalidade e mortalidade, mantendo a população sob controle.

Esse modelo apresentado por Malthus vai de encontro a ideia desenvolvimentista, no qual tem como princípio básico o encremento da renda per capita. Ademais, a transição demográfica (redução das taxas de fecundidade e mortalidade) teve relação com o desenvolvimento econômico, nos quais, de acordo com Alves (2002, p. 29), a partir dos processos de modernização ocorridos na Europa Ocidental, América do Norte e Oceania, "trouxe grandes ganhos de produtividade que possibilitaram o aumento da oferta de bens em geral, e de bens de subsistência, em particular, o que resultou em melhorias no padrão de vida da população".

Dessa forma, mais tarde, um dos motivos que levou os governantes a pensarem na preservação do meio ambiente foi porque, de acordo com Minc (2005, p. 77), "Numerosas doenças têm origem em fatores ambientais, como a poluição, a falta de saneamento, a má qualidade da água e da alimentação. Por exemplo, o desmatamento e a falta de higiene sanitária permitem a proliferação do mosquito da dengue. " Dentre a preservação do meio ambiente, estava o controle da poluição que era obrigação de todos os entes da federação, cada qual atuando nos limites de sua competência e território. Contudo, na época, poucas eram as legislações específicas e sistemáticas para tratar desse assunto.

Hely Lopes Meirelles (1979) destaca que havia referência aos cuidados e preservação dos recursos naturais, assim entendidos como sendo a terra, a água, as jazidas, as florestas, a fauna e o espaço aéreo. Um bom exemplo foram as conclusões do Clube de Roma ${ }^{7}$ publicadas em 1972, ao apresentarem um relatório chamado Limites do Crescimento, demonstrando a impossibilidade do ritmo e do estilo de desenvolvimento praticado pelos países ricos em face do previsível esgotamento das fontes de energia e dos recursos naturais (MINC, 2005). Contudo, ao alardearem

\footnotetext{
${ }^{7}$ Organização que reunia os países mais ricos do globo.
} 
a extinção dos bens minerais conseguiram deslocar o foco do problema, que era as condições de trabalho dos mineiros para o meio ambiente. Além do controle da poluição e da preservação dos recursos naturais, Hely Lopes Meirelles (1979) assinala que se fazia necessária a restauração dos elementos destruídos ou degradados pelo homem e pelos fenômenos da natureza, objetivando configurar a completa proteção ambiental. Observa-se, portanto, que não havia sequer menção a respeito da poluição visual.

Por outro lado, até meados da década de 1980 houve uma forte resistência por parte dos empresários em tomar qualquer iniciativa de amenizar os impactos socioambientais decorrentes da atividade produtiva, com a justificativa de que os custos para prevenir a degradação ambiental comprometeriam sua lucratividade e sua capacidade competitiva. Nese sentido disserta Jacques Demajorovic (2003, p. 33):

Até meados da década de 1980, predominou no discurso empresarial uma resistência a qualquer iniciativa de minimizar os impactos socioambientais decorrentes da atividade produtiva. No que se referia especificamente aos problemas de degradação ambiental, os representantes empresariais argumentavam que os custos adicionais para as empresas, resultantes dos gastos em controle de poluição, comprometeriam a lucratividade, a competitividade e a oferta de empregos, gerando, portanto, prejuízos às partes interessadas, ou seja, trabalhadores, acionistas e consumidores. Nesse contexto, as estratégias das empresas era, segundo o jargão econômico, externalizar os custos ambientais, ou seja, transferi-los para a sociedade, poupando o verdadeiro causador de arcar com qualquer ônus para reverter o problema."

Somente a partir da década de 1980, na Alemanha, iniciou-se um movimento defendendo que a atenção às normas ambientais representava um investimento que traria vantagens competitivas no futuro para seu negócio. Com isso, Demajorvic (2003) explica que o discurso empresarial que reconhecia e elogiava as empresas como instrumento único para fomentar riquezas perdia espaço na sociedade para dar lugar a institucionalização da sua responsabilidade ambiental.

A Lei no 6.938/81 - Política Nacional do Meio Ambiente - foi considerada um avanço no que diz respeito à proteção ambiental, voltada ao interesse coletivo e tendo como objetivo "a preservação, melhoria e recuperação da qualidade ambiental propícia à vida, visando assegurar, no País, condições ao desenvolvimento socioeconômico, aos interesses da segurança nacional e à proteção da dignidade da vida humana", nos termos do caput de seu art. $2^{\circ}$. Seguindo essa mesma linha de raciocínio, em 1985, foi disciplinada a Ação Civil Pública de responsabilidade por danos causados ao meio ambiente, ao consumidor, a bens e direitos de valor artístico, estético, histórico, 
turístico e paisagístico, através da Lei № 7.347/85. A referida legislação deixou à disposição um conjunto de elementos processuais, para defender as ameaças ou as lesões ao meio ambiente.

Por fim, a Constituição Federal de 1988 mantém a possibilidade de tutela individual, mas, em seu artigo 225, prevê a tutela de bens coletivos, garantindo, assim, um meio ambiente equilibrado dos bens de uso comum do povo e essenciais à sadia qualidade de vida. É preciso também não nos esqueçamos da Lei no 9.605/98, que trata sobre as sanções penais e administrativas, derivadas de condutas e atividades lesivas ao meio ambiente. Certamente, esse movimento legislativo sofreu grande influência das conferências realizadas pela Organização das Nações Unidas (ONU), para tratar acerca do meio ambiente e, dentre elas, destacam-se: a Declaração de Estocolmo (1972), em Estocolmo, a Conferência das Nações Unidas sobre Meio Ambiente e Desenvolvimento (CNUMAD), chamada de Eco-92, no Rio de Janeiro (1992); e a Cúpula Mundial sobre Desenvolvimento Sustentável denominada Rio+10, em Joanesburgo, em 2002. (FIORILLO, 2011).

A Constituição Federal de 1988 não desconsiderou que os recursos ambientais fossem utilizados para o desenvolvimento da atividade econômica. Ao contrário, conforme explica Paulo de Bessa Antunes (2007, p. 56), "o legislador constituinte buscou estabelecer um mecanismo mediante o qual as naturais tensões entre os diferentes usuários dos recursos ambientais possam ser amenizadas dentro de uma perspectiva de utilização racional".

O surgimento de normas ambientais, imbuídas de diversos princípios que também foram absorvidos pela Constituição Federal de 1988 e que são aqui destacadas, são classificadas por Celso Antônio Pacheco Fiorillo (2011), as quais serão analisadas a seguir.

\section{Tipos de princípios 8}

Princípio do desenvolvimento sustentável

O caput do art. 225 da Constituição de 1988 tem como escopo conscientizar a população de que os recursos naturais não são inesgotáveis e a sua utilização deve ser feita de forma responsável, porque este comportamento irá condicionar "a manutenção das bases vitais da produção e reprodução do homem e de suas atividades". (FIORILLO, 2011, p. 83). Nesse contexto, deve-se buscar um ponto de equilíbrio entre a preservação ambiental e o desenvolvimento

\footnotetext{
${ }^{8}$ Os princípios citados (2.1.1 e segs.) foram retirados da obra de Celso Antônio Pacheco Fiorillo, Curso de Direito Ambiental brasileiro (2011).
} 
econômico, o que demanda um adequado planejamento territorial que leve em conta os limites da sustentabilidade.

Princípio do poluidor-pagador

O princípio do poluidor-pagador tem dois objetivos:

1. Um caráter preventivo, para que não se pratique o dano ambiental, ou seja, o poluidor tem que utilizar mecanismos, a fim de evitar que o dano aconteça; e

2. Um caráter repressivo, no sentido de buscar reparação, quando o dano aconteceu. Se o dano aconteceu em função da atividade desenvolvida pelo poluidor, ele será responsável por sua reparação. Sobre esse princípio, assinala-se que a responsabilidade civil aos danos ambientais está ligada diretamente a cinco formas de incidência e aplicação, as quais serão apresentadas a seguir:

I. Responsabilidade civil objetiva

Existindo nexo entre a materialidade do dano e a atividade desenvolvida pelo poluidor, ele é responsável por reparar os danos, sem a necessidade de aferir sua culpabilidade. Registra-se, nas palavras de Celso Antônio Pacheco Fiorillo (2011, p. 99), que “a adoção pela Constituição Federal do regime da responsabilidade objetiva implica a impossibilidade de alteração desse regime jurídico da responsabilidade civil, em matéria ambiental, por qualquer lei infraconstitucional". [Grifo do autor].

II. Prioridade da reparação

A reparação ao dano ambiental pode ser feita de forma natural ou indenizatória. Na forma natural, verifica-se a possibilidade de restaurar por completo ou, ao menos, bem aproximado, o estado anterior do ambiente. Pode não ser possível restaurar, de forma idêntica, o ambiente afetado, mas a reparação faz a contraprestação nos mesmos moldes (por exemplo, no caso de corte de árvores, o causador do dano deverá plantar árvores), e é mais vantajoso do que a indenização monetária. Caso não seja possível reverter o dano ou fazer a reparação específica, a condenação recairá sobre um valor pecuniário.

III. Poluidor

É considerado poluidor toda a pessoa física ou jurídica (de direito público ou privado) que, de alguma forma, foi o causador do dano ambiental. Caracteriza-se a poluição, de acordo com Celso Antônio Pacheco Fiorillo (2011, p. 101), “como a degradação da qualidade ambiental, ou seja, com a ocorrência de qualquer alteração adversa das características do meio ambiente". 


\section{Dano Ambiental}

Dano ambiental é aquele que causa uma lesão a um bem jurídico que, no caso deste estudo, é o meio ambiente. Os danos podem ser patrimoniais e extrapatrimoniais. Os patrimoniais são aqueles que atingem interesses relativos a bens materiais, representando sua deterioração ou perda; e os extrapatrimoniais, os que ofendem interesses não corpóreos, representados pelos valores imateriais da pessoa humana.

\section{Solidariedade}

Todos os causadores de um dano ambiental são chamados a responder por ele de forma solidária, ou seja, todos podem ser indicados como parte legítima, para serem responsabilizados em caso de processos administrativos ou judiciais.

Princípio da prevenção

No tocante ao princípio de prevenção, destaca-se o pensamento de Celso Antônio Pacheco Fiorillo (2011), por considerá-lo um dos princípios de maior relevância, para nortear o Direito Ambiental. Por ser a prevenção uma doutrina fundamental, em geral, os danos ambientais são irreversíveis e irreparáveis. Espécies, quando de sua extinção, ou os efeitos de um acidente nuclear ou ainda a devastação de uma floresta rica em ecossistemas diferentes, tem possibilidade de reparação? O sistema jurídico é incapaz de restabelecer tais danos, mas, utilizando-se do princípio da prevenção do dano ao meio ambiente, e o Direito Ambiental é consolidado em seu objetivo fundamental.

O princípio da prevenção é abordado pela Constituição Federal de 1988 no caput do art. 225, o dever do Poder Público e da coletividade de proteger e preservar o meio ambiente para as presentes e futuras gerações. Consoante explica Fiorillo (2011, p. 125-128), desde a Conferência de Estocolmo (1972) esse princípio é destacado como um 'megaprincípio de direito ambiental', estando presente, também, na ECO-92. No entanto, a falta de comprovação científica, sempre foi argumento para obstaculizar as ações de preservação do meio ambiente, por sofrer de "incipiente especificação de conteúdo normativo" (FIORILLO, 2011, p. 130). Contemporaneamente, na forma como esse princípio se apresenta, ele "limita-se a afirmar que a falta de certeza científica não deve ser usada como meio de postergar a adoção de medidas preventivas, quando houver ameaça séria de dano irreversível" (FIORILLO, 2011, p. 130). Apresenta-se como um conceito aberto que 
depende da interpretação do agente público ou do julgador, no caso da discussão chegar ao judiciário9.

Apesar deste princípio estar evidente em texto constitucional, tornou-se necessária a utilização de outros instrumentos, tais como: o estudo prévio de impacto ambiental, o manejo ecológico, o tombamento, as liminares, as sanções administrativas etc. Não com o intuito de desvirtuar este princípio, mas as multas e as punições severas, impostas por lei, também acabam auxiliando na prevenção de problemas ambientais

Princípio da participação

Esse princípio trata do dever de preservação de um meio ambiente equilibrado, através do agir em conjunto, ou seja, que ações sejam feitas pelo Poder Público e pela sociedade civil, para atingir este fim $\mathrm{O}$ dever de tutela do meio ambiente cabe à coletividade, e, para que as ações sejam tomadas em conjunto ou que haja o envolvimento coletivo, são necessárias ações complementares, quais sejam:

1. A informação ambiental;

2. A educação ambiental; e

3. A política nacional de educação ambiental.

A informação ambiental (1) tem respaldo nos arts. $6^{\circ}, \S 3^{\circ}$, e 10 da Política Nacional do Meio Ambiente e engloba o direito de informação e de ser informado (arts. 220 e 221 da Constituição). Está interligado à educação ambiental, porque está se faz a partir de informações. Já a educação ambiental (2) decorre do princípio da participação, na proteção ao meio ambiente. Nesta perspectiva, busca-se conscientizar a população, para que proteja o meio ambiente de várias formas, uma vez que as próprias pessoas são titulares desse direito. E por fim, a política nacional de educação ambiental (3) se concretiza através da Lei no 9.795/99, ao definir que, a partir da

\footnotetext{
${ }^{9}$ No Recurso Extraordinário n. 627.189 (SP), julgado pelo STF em 22/09/2011 (reconhecendo a repercussão geral do tema), em ação movida pela Sociedade Amigos do Bairro City Boaçava e outros contra a Eletropaulo Metropolitana, discute-se decisão da Câmara Especial do Meio Ambiente do TJSP que condenou a concessionária a adotar medidas para reduzir a intensidade dos campos eletromagnéticos originados das linhas de transmissão, uma vez que, embora inexista um laudo conclusivo sobre o assunto, não é possível desconsiderar que as investigações realizadas até aquele momento, a grande possibilidade dos campos eletromagnéticos de baixa frequência serem agente cancerígenos para os seres humanos aplicando-se, assim, o princípio da precaução: "sempre que houver uma probabilidade mínima que o dano ocorra como consequência da atividade suspeita de ser lesiva, necessária se faz providência de ordem cautelar o princípio é corolário da diretiva constitucional que assegura o direito ao meio ambiente ecologicamente equilibrado e à sadia qualidade de vida [...]".
} 
educação ambiental, os indivíduos e a coletividade formarão seus valores e atitudes, para que ocorra a preservação do meio ambiente. Deve ser implementada na educação formal, começando pelo ensino fundamental até a graduação e pós-graduação, e através de ações práticas que sensibilizem a coletividade sobre as questões ambientais.

Princípio da ubiquidade

Esse princípio determina que, toda vez que uma política ou legislação sobre qualquer tema for criada, deverá levar em consideração as questões de proteção ambiental e verificar se existe ou não, a possibilidade de o meio ambiente ser degradado.

Observa-se que os referidos princípios estão voltados para a questão da preservação da vida e da qualidade de vida, estabelecidos na Constituição Federal de 1988, uma vez que os indivíduos são parte integrante do meio ambiente e, sempre que ele for violado, também se atinge a coletividade. Na esteira, leciona Walter Ceneviva (2003, p. 425):

O homem tomou conhecimento, no século XX, da necessidade de preservar o meio ambiente, como garantia de sua própria vida. O conhecimento surgiu aos poucos, diante dos efeitos danosos provocados pela rápida transformação das condições de habitabilidade, em todo o planeta.

Até aqui se demonstrou a relação do meio ambiente com a legislação constitucional, já que ela é o Norte a ser seguido pelas legislações infraconstitucionais. A partir de agora, seguiremos com a relação constitucional e a legislação que determina o gerenciamento, entre outras coisas, da proteção ao meio ambiente pelos municípios.

\section{A Legislação Ambiental Federal e Infraconstitucional}

A partir da Constituição de 1988, o Brasil, de forma inaugural, é contemplado com o instituto do plano diretor, através do artigo 182, que é um instrumento básico da política de desenvolvimento urbano, sendo o Município o executante, conforme nos ensina Mukai (2004, p. 29). Essa legislação tem o objetivo de comandar o pleno desenvolvimento das funções sociais da cidade e assegurar o bem-estar de sua população, conforme o $\$ 2^{\circ}$ do artigo 182. O Plano Diretor, por meio da aprovação da lei municipal, deverá ter o aparelhamento necessário na aplicação dessa política e da expansão urbana.

Hely Lopes Meirelles (1979, p. 101-102), de forma precisa, conceitua o Plano de Desenvolvimento Integrado. Neste momento, verificamos os três pontos fundamentais para uma 
melhor compreensão da importância do Plano Diretor no direcionamento futuro dos municípios, atendendo ao desejo de seus munícipes:

1. O Plano Diretor ou Plano Diretor de Desenvolvimento Integrado, como modernamente se diz, é o complexo de normas legais e diretrizes técnicas para o desenvolvimento global, constante do Município, sob os aspectos físico, social, econômico e administrativo, desejado pela comunidade local.

2. É o instrumento técnico-legal definido dos objetivos de cada Municipalidade e por isso mesmo com supremacia sobre os outros, para orientar toda atividade da Administração e dos Administrados nas realizações públicas e particulares que interessem ou afetem a coletividade.

3. Na fixação dos objetivos e na orientação do desenvolvimento do Município é a lei suprema e geral que estabelece as prioridades nas realizações do governo local, conduz e ordena o crescimento da cidade, disciplina e controla as atividades urbanísticas em benefício do bem-estar social.

Após a promulgação da Constituição Federal, em 1988, a legislação infraconstitucional mais importante no regramento dos municípios da federação é a Lei no 10.257, de 10 de julho de 2001, conhecida como 'Estatuto das Cidades'. Essa lei surgiu a partir de um Projeto de Lei que iniciou a sua tramitação no ano de 1989, apenas um ano após a promulgação da nossa Constituição, e tinha como objetivo ordenar, de forma igualitária, as políticas municipais.

Destaca-se que o Estatuto das Cidades em suas diretrizes, nas questões ambientais relacionadas à proteção, preservação e recuperação do meio ambiente, não só natural, mas também, o construído, o patrimônio cultural, histórico, artístico, paisagístico e arqueológico. A Lei no 10.257 teve como propósito explicitar os mandamentos contidos nos Arts. 182 e 183 da Constituição Federal de 1988, visando a regular o uso da propriedade urbana em favor da coletividade, da segurança e do bem-estar dos indivíduos e do equilíbrio ambiental, ou seja, à proteção ambiental do ambiente urbano.

Destaca-se ainda um dos aspectos relevantes da referida Lei, o fato de constituir-se de um instrumento que permite a efetiva concretização do Plano Diretor nos municípios brasileiros, sendo obrigatório em cidades com mais de vinte mil habitantes. Cabe também enfatizar que se trata de ferramenta da aplicação da política de desenvolvimento urbano, tais como o parcelamento e as edificações compulsórios, o IPTU, progressivo no tempo, e a desapropriação, com pagamento em 
títulos. Paulo de Bessa Antunes (2007, p. 319) explica a importância do Plano Diretor na organização das cidades:

O instrumento jurídico mais importante para a vida das cidades é o Plano Diretor, pois é dele que se origina todas as diretrizes e normativas para a adequada ocupação do solo urbano.

(...)

O Plano Diretor é lei formal, não podendo ser substituído por decreto ou outro ato administrativo de qualquer natureza. Como instrumento básico da política de desenvolvimento e expansão urbana, ele é parte integrante e indissociável do processo de planejamento municipal.

No ano de 2003, foi criado o Ministério das Cidades, respaldando a efetiva aplicação do Estatuto das Cidades junto aos municípios brasileiros. Assinala-se igualmente o pensamento de Mukai (2004, p. 31-32), sendo apontados três pontos jurídicos referentes ao tema: (a) primeiro, que a Constituição Federal de 1988, em seu artigo 182, $\S 1^{\circ}$, torna obrigatória a aprovação de um Plano Diretor para cidades com mais de vinte mil habitantes, e o Estatuto das Cidades, em seu artigo 41, artigo 52 e artigo 54, concretiza essa obrigatoriedade; (b) constatou-se, também, a possibilidade da existência de planos nacionais, estaduais (regionais) e metropolitanos de desenvolvimento urbano de forma simultânea (MEIRELLES, 1979) à saciedade e à legalidade da aprovação destes planos; e (c) os planos nacionais, estaduais e regionais, inclusive os metropolitanos que obrigam os municípios a observem tais planos.

No intuito de promover uma gestão democrática da cidade, o Estatuto da Cidade, Lei no 10.257/2001, em seu artigo 43 e inciso o, institui a obrigatoriedade de criação de órgãos colegiados de política urbana nas três esferas de governo "Art. 43. Para garantir a gestão democrática da cidade, deverão ser utilizados, entre outros, os seguintes instrumentos I - órgãos colegiados de política urbana, nos níveis nacional, estadual e municipal”. (BRASIL, 2001).

Atendendo ao disposto desse artigo, o executivo federal cria, por intermédio da Medida Provisória no 2.220/2001, em seu artigo 10ㅡ, o Conselho Nacional de Desenvolvimento Urbano (CNDU), sendo este um órgão deliberativo e consultivo, ligado à Presidência da República.

Relacionado à competência desse conselho, destacamos a proposição de diretrizes, instrumentos, normas e prioridades da política nacional de desenvolvimento urbano, conforme o inciso lo do artigo 10:

Art. 10. Fica criado o Conselho Nacional de Desenvolvimento Urbano - CNDU, órgão deliberativo e consultivo, integrante da estrutura da Presidência da República, com as seguintes competências:

I. Propor diretrizes, instrumentos, normas e prioridades da política nacional de desenvolvimento urbano. (BRASIL, 2001). 
Com a posse do Presidente Luiz Inácio Lula da Silva em 2003, foi aprovada a Lei no 10.683/2003, de iniciativa do executivo, que dispõe sobre a organização da Presidência da República e dos Ministérios. No seu artigo 31, inciso VIII, a Secretaria Especial de Desenvolvimento Urbano da Presidência da República foi transformada em Ministério das Cidades. Na mesma lei, no artigo 33, inciso VIII, o Conselho Nacional de Desenvolvimento Urbano (CNDU), ligado à Presidência da República, foi transferido para o Ministério das Cidades, ficando alterada a sua denominação para 'Conselho das Cidades', cabendo-Ihe, além das competências do CNDU, propor as diretrizes para a distribuição regional e setorial do orçamento do Ministério das Cidades.

A regulamentação do Conselho das Cidades se deu através do Decreto no 5.790/2006:

Art. 1 O O Conselho das Cidades - ConCidades, órgão colegiado de natureza deliberativa e consultiva, integrante da estrutura do Ministério das Cidades, tem por finalidade estudar e propor as diretrizes para a formulação e implementação da Política Nacional de Desenvolvimento Urbano, bem como acompanhar e avaliar a sua execução, conforme dispõe a Lei no 10.257, de 10 de julho de 2001 - Estatuto da Cidade.

Art. 2 o O ConCidades é responsável por propor as diretrizes gerais para a formulação e implementação da Política Nacional de Desenvolvimento Urbano, em consonância com as resoluções aprovadas pela Conferência Nacional das Cidades. (BRASIL, 2006).

O Conselho das Cidades, por meio de sua Resolução no 34/2005 e considerando a efetividade dos instrumentos previstos no Estatuto da Cidade, destinados a ordenar o pleno desenvolvimento das funções sociais da cidade e da propriedade "em prol do bem coletivo, da segurança e do bem-estar dos cidadãos, bem como do equilíbrio ambiental", passou a emitir orientações e recomendações a serem inseridas nos Planos Diretores Municipais.

Na Resolução no 34/2005, o ConCidades dispõe em dois momentos sobre a preservação e a recuperação do meio ambiente natural e construído, do patrimônio cultural, histórico, artístico e paisagístico, tema abordado nesta monografia. Primeiramente, em seu artigo 2o e inciso Io, o qual trata das funções sociais da cidade e da propriedade urbana, são definidas áreas de proteção, preservação e recuperação do meio ambiente natural e construído, do patrimônio cultural, histórico, artístico, paisagístico e arqueológico. Em segundo e de igual importância, no artigo 5 e inciso VII, a criação de zonas especiais, de interesse local, demarcando as áreas de proteção, preservação e recuperação do meio ambiente natural e construído, do patrimônio cultural, histórico, artístico, paisagístico e arqueológico:

Art. 2 ㅇ As funções sociais da cidade e da propriedade urbana serão definidas a partir da destinação de cada porção do território do município bem como da identificação dos imóveis não edificados, subutilizados e não utilizados, no caso de sua existência, de forma a garantir: 
I. Espaços coletivos de suporte à vida na cidade, definindo áreas para atender as necessidades da população de equipamentos urbanos e comunitários, mobilidade, transporte e serviços públicos, bem como áreas de proteção, preservação e recuperação do meio ambiente natural e construído, do patrimônio cultural, histórico, artístico, paisagístico e arqueológico;

Art. 5ㅇ. A instituição das Zonas Especiais, considerando o interesse local, deverá:

(...)

VII. Demarcar as áreas de proteção, preservação e recuperação do meio ambiente natural e construído, do patrimônio cultural, histórico, artístico, paisagístico e arqueológico. (BRASIL, 2005).

São muitos os desafios na tutela ambiental, no que tange à inserção da função social da propriedade e da cidade, as quais esbarram em interesses privados e, principalmente, ligados ao mercado de consumo em contraponto à proteção ambiental que se faz necessária. Todavia, o alcance da política urbana, na criação de mecanismos de controle, tem sido aperfeiçoado, apresentando resultados positivos ao logo desta jornada de proteção ambiental.

\section{A Legislação Ambiental Municipal}

Determinar atribuições legislativas e administrativas aos municípios é de suma importância, uma vez que são eles os mais próximos da realidade local. Paulo de Bessa Antunes (2007, p. 85) defende esse entendimento:

A importância dos Municípios é evidente por si mesma, pois as populações e as autoridades locais reúnem amplas condições de bem conhecer os problemas e mazelas ambientais de cada localidade, sendo certo que são as primeiras a localizar e identificar o problema.

Os planos urbanísticos são parte integrante do Direito Urbanístico que tratam das normas que se enquadram como matéria que concorre nos três níveis de governo. A observância pelo Município, ao aprovar o seu plano, em princípio, obriga que estejam em consonância com os planos estaduais e metropolitanos. Mas, em casos conflitantes de normas e diretrizes, contemplando estes temas de maior repercussão nas necessidades locais e menos nas de interesse geral, o Plano Diretor deve prevalecer sobre os planos nacionais, estaduais ou metropolitanos. Além disso, diversas legislações municipais, respaldadas pela Constituição Federal de 1988, têm priorizado, em seus textos, as questões ambientais.

Ao falar sobre poluição, logo se imagina dejetos, sendo jogados em um rio, ar contaminado por poeiras, gases tóxicos, entre outros. Difícil é pensar que a questão visual pode ser um caso de poluição. Contudo, qualquer alteração das propriedades físicas, químicas e biológicas do ambiente, 
no sentido de degradação, é considerada relevante, porque gera impacto ambiental. Nesta perspectiva, a Resolução $n^{\circ}$ 1/86, do Conselho Nacional do Meio Ambiente (CONAMA), em seu artigo $1^{\circ}$, estabelece o conceito normativo de impacto ambiental:

Art. 10 Para efeito desta Resolução, considera-se impacto ambiental qualquer alteração das propriedades físicas, químicas e biológicas do meio ambiente, causada por qualquer forma de matéria ou energia resultante das atividades humanas que, direta ou indiretamente, afetam:

I. A saúde, a segurança e o bem-estar da população;

II. As atividades sociais e econômicas;

III. A biota;

IV. A qualidade dos recursos ambientais. (BRASIL, 1986).

Tendo em vista ser o meio ambiente um bem coletivo, necessita de proteção para as atuais e futuras gerações, o qual recebe um tratamento diferenciado, tanto pela Constituição Federal de 1988 quanto pelas demais legislações infraconstitucionais. Os municípios têm importante papel nesse contexto, já que possuem esta tutela, por meio da qual têm o dever de regulamentar temas de impacto ambiental com efeito local.

Tratando-se de poluição visual, no município de São Paulo, no ano de 2006, foi criada a Lei no 14.223, que ordenou os elementos que compõem a paisagem urbana do município, assim como as suas diretrizes, aperfeiçoando, em nível municipal, a garantia dos direitos fundamentais. Enfatiza-se que a tutela ambiental trata com destaque da poluição visual, nos artigos 3o e 4ㅇ. São observadas no artigo 3 e assegurados nos incisos 으, III으 e VI으, o bem-estar estético, cultural e ambiental da população, a valorização do ambiente natural e construído, além da preservação da memória cultural:

Art. 3o Constituem objetivos da ordenação da paisagem do Município de São Paulo o atendimento ao interesse público em consonância com os direitos fundamentais da pessoa humana e as necessidades de conforto ambiental, com a melhoria da qualidade de vida urbana, assegurando, dentre outros, os seguintes:

I. O bem-estar estético, cultural e ambiental da população; $(\ldots)$

II. A valorização do ambiente natural e construído; (...)

III. A preservação da memória cultural; (SÃO PAULO, 2006).

A Lei no 14.223/2006 do município de São Paulo trata com objetividade e coloca como diretriz, no seu artigo 4ํㅡ, inciso III으 o combate à poluição visual e a degradação ambiental: 
Art. 4o Constituem diretrizes a serem observadas na colocação dos elementos que compõem a paisagem urbana:

(...)

III. O combate à poluição visual, bem como à degradação ambiental;

IV. A proteção, preservação e recuperação do patrimônio cultural, histórico, artístico, paisagístico, de consagração popular, bem como do meio ambiente natural ou construído da cidade; (SÃO PAULO, 2006) [grifo nosso] .

Em relação ao tema abordado neste estudo, o papel dos municípios na tutela ambiental é de grande importância, em especial, no tocante à elaboração de leis de controle de impacto local, causado pela poluição visual. Resultados nas cidades com esta legislação específica são constatados desde sua publicação e durante seu período de vacatio legis.

\section{A LEGISLAÇÃO AMBIENTAL DE CAXIAS DO SUL}

Neste capítulo, são analisadas três legislações do Município de Caxias do Sul: o Plano Diretor, através de seu enfoque ambiental, e a Lei № 412/2012, que trata especificamente da poluição visual, e o seu controle.

\section{Lei Orgânica Municipal}

A Lei Orgânica Municipal é a lei maior no âmbito municipal, com sua obrigatoriedade constitucional definida em seu artigo 29. Segundo Jorge Bernardi (2012), é a lei que dirige e organiza o município, sendo esta indispensável para a ordenação do município. Tal lei para o município é como a Constituição é para a nação. Todas as demais legislações são subordinadas e dependentes a ela ou padecem de sua influência.

Outra característica da Lei Orgânica é que o prefeito não participa de sua elaboração, sendo desde a autoria até a sua promulgação de responsabilidade exclusiva da Câmara de Vereadores, conforme o que rege o caput do artigo 29 da Constituição Federal de 1988:

Art. 29. O Município reger-se-á por lei orgânica, votada em dois turnos, com o interstício mínimo de dez dias, e aprovada por dois terços dos membros da Câmara Municipal, que a promulgará, atendidos os princípios estabelecidos nesta Constituição, na Constituição do respectivo Estado. (BRASIL, 1988).

No Município de Caxias do Sul, a Lei Orgânica Municipal foi promulgada em 04 de abril de 1990. Destacamos uma emenda de cunho ambiental muito importante, a Emenda à Lei Orgânica no 40, de 1 ㅇ de março de 2012, na qual o legislador municipal acrescentou um capítulo específico 
sobre o tema Ambiental. Em seu artigo 244-A, caput, é demonstrada sua identidade com o princípio do desenvolvimento sustentável, onde é transcrita esta tutela do meio ambiente:

Art. 244-A. Todos têm direito a um meio ambiente saudável e ecologicamente equilibrado, considerado como bem de uso comum da população e essencial à adequada qualidade de vida, impondo-se a todos e, em especial, ao Poder Público Municipal o dever de defendê-lo e preservá-lo para o benefício das gerações atuais e futuras. (CAXIAS DO SUL, 1990).

O legislativo concebeu, por meio do artigo 244-A, da Lei Orgânica Municipal, em seu parágrafo único, uma ligação entre a Secretaria Municipal do Meio Ambiente e os diversos órgãos municipais quanto ao tratamento das políticas ambientais. Essa conexão se completa por intermédio da sociedade, através do Sistema Municipal do Meio Ambiente abrangido pela Política Municipal do Meio Ambiente, pelo Conselho Municipal do Meio Ambiente e pelo Fundo Municipal do Meio Ambiente:

Parágrafo único. As políticas públicas municipais deverão ser articuladas pela Secretaria Municipal do Meio Ambiente de forma transversal com os demais órgãos e através do Sistema Municipal do Meio Ambiente, que abrangerá, entre outros, os seguintes instrumentos:

I. Política Municipal do Meio Ambiente;

II. Conselho Municipal do Meio Ambiente; e

III. Fundo Municipal do Meio Ambiente. (CAXIAS DO SUL, 1990).

A Lei Orgânica ainda trata, em seu artigo 38, inciso VII, da competência do município em elaborar seu Plano Diretor Municipal, e, no artigo 144, inciso II, da definição das diretrizes ambientais em relação ao planejamento e à implementação da política de desenvolvimento municipal: "Art. 144. Plano Diretor é o instrumento básico do planejamento e da execução da política de desenvolvimento do Município, devendo definir [...] II - diretrizes ambientais". (CAXIAS DO SUL, 1990).

O Plano Diretor estabelecerá regras no que concerne à proteção ao patrimônio histórico e cultural do município, segundo a Lei Orgânica, através do artigo 193, parágrafo 2ํ․

\section{Plano Diretor Municipal}

No ano de 1972, foi instituído o primeiro plano diretor no município de Caxias do Sul, através da lei ordinária no 2087/1972, que se refere à organização das edificações e o zoneamento urbano, bem como à definição de seu perímetro urbano, sendo classificado por categorias construtivas.

Questões ambientais são tratadas superficialmente, apenas contempladas em seu artigo 9o, nas categorias 10a e 12a de forma positiva, que limita o nível de ruído em 60 decibéis, que 
estabelece que não sejam produzidos cheiros, fumaça ou outro efeito molesto à vizinhança; e, de forma negativa, nas categorias 11a e 13ạ , em que é permitido o nível de ruído acima de 60 decibéis, além da produção de cheiros, fumaça ou outro efeito molesto, conforme texto da Lei no 2087/1972:

Art. 9o - Para os efeitos desta lei as construções ficam classificadas nas seguintes categorias segundo o uso que delas for feito:

(...)

10a Categoria - Oficinas ou fábricas destinadas a atividade que não produza ruído acima de 60 decibéis, nem cheiro, nem fumaça outro efeito molesto à vizinhança a critério da Prefeitura e que não ocupe mais de 10 pessoas no local.

11a Categoria - Oficinas ou fábricas destinadas a atividade que produza ruído acima de 60 decibéis ou cheiro ou fumaça outro qualquer efeito molesto a critério da Prefeitura ocupando não mais de 10 pessoas no local.

12a Categoria - Oficinas ou fábricas destinadas a atividade que não produza ruído acima de 60 decibéis nem cheiro nem fumaça nem outro qualquer efeito molesto a critério da Prefeitura e que ocupe mais de 10 pessoas no local.

13a Categoria - Oficinas ou fábricas destinadas a atividade que produza ruído acima de 60 decibéis, ou cheiro ou fumaça ou outro efeito molesto a critério da Prefeitura e que ocupe mais de 10 pessoas no local. (CAXIAS DO SUL, 1972).

Através da Constituição Federal de 1988, o constituinte, no propósito de ordenar o pleno desenvolvimento das funções sociais da cidade e garantir o bem-estar de seus habitantes, norteou a política de desenvolvimento urbana nos municípios, e, de forma obrigatória, para cidades com mais de vinte mil habitantes, através da instituição de um Plano Diretor.

Mais tarde, por meio do Estatuto das Cidades, Lei no 10.257/2001, o Plano Diretor foi ordenado, e, a partir desse momento, os municípios, por meio de suas câmaras de vereadores, têm um prazo para a criação e a aprovação do Plano Diretor Municipal.

O Município de Caxias do Sul, apesar de possuir o seu Plano Diretor desde 1972, necessita que seja feito o enquadramento deste na obrigatoriedade constitucional. Salienta-se que a regulamentação de seu Plano Diretor Municipal ocorre por intermédio da Lei Complementar no 290, de 24 de setembro de 2007. Em seu parágrafo primeiro, são apresentadas as diretrizes que o Plano Diretor irá tratar, tomando um caráter técnico e político; as recomendações para as ações de seus agentes públicos e privados quanto à utilização dos espaços urbano e rural; e, ainda, as regras focadas em suas atividades, na visão de desenvolvimento do município e em sua eficiência em administrar: 
Art. 10 O Plano Diretor Municipal é o instrumento técnico e político básico de orientação das ações dos agentes públicos e privados no uso dos espaços urbano e rural para as diversas atividades, com vista ao desenvolvimento do Município e à eficiência administrativa. (CAXIAS DO SUL, 2007).

Cabe salientar igualmente que o artigo segundo da mesma lei trata, nos incisos I, VI e VIII, dos temas ambientais, como princípios, seguindo os preceitos constitucionais ambientais:

Art. 2o São princípios do Plano Diretor Municipal:

I. O desenvolvimento equilibrado e sustentável nos planos físico, social, cultural, econômico e ambiental;

(...)

VI. A integração dos órgãos e das políticas públicas de desenvolvimento sustentável municipal e regional;

(...)

VIII. A preservação do meio ambiente natural e do equilíbrio ecológico, respeitadas as vocações locais. (CAXIAS DO SUL, 2007).

Neste sentido, o Plano Diretor, estando centrado nas questões ambientais de forma prioritária, tem uma seção específica que busca desenvolver uma política de preservação ambiental nos seus artigos 54 e incisos, no artigo 55, bem como no artigo 56 e incisos.

Destaca-se, nesse texto legislativo, a ligação com o tema abordado neste estudo que trata da poluição visual e o seu controle no Município de Caxias do Sul, onde a Lei do Plano Diretor Municipal, em seu artigo 54, estabelece que é preciso "assegurar o direito da sociedade a uma vida saudável". (CAXIAS DO SUL, 2007).

\section{A Lei Municipal № 412/2012}

A legislação ambiental no Município de Caxias do Sul, nas últimas décadas, tem tratado a política ambiental nos moldes constitucionais da sustentabilidade, sendo esta legislação consolidada por intermédio da Lei Complementar no 376/2010, relativa à Política Municipal do Meio Ambiente. $\mathrm{O}$ artigo primeiro trata de seus princípios fundamentais, dando enfoque à responsabilidade do poder público municipal e dos cidadãos em proteger o meio ambiente, garantindo, assim, ao conjunto da sociedade uma vida saudável. Através do inciso ॥o, trata do princípio de que o meio ambiente é considerado um patrimônio público e necessita de proteção, além de ser ainda garantida a melhoria na qualidade de vida da coletividade:

Art. 1ํ A Política do Meio Ambiente objetiva a responsabilidade comum do Poder Público Municipal e do cidadão em proteger o ambiente, assegurar o direito da sociedade a uma vida saudável e garantir que a exploração dos recursos ambientais não comprometa as necessidades das presentes $\mathrm{e}$ futuras gerações, atendendo aos seguintes princípios fundamentais:

(...) 
II. Ação governamental na manutenção da estabilidade dos ecossistemas, considerando o ambiente como um patrimônio público a ser necessariamente protegido, tendo em vista o uso coletivo e a melhoria da qualidade de vida; (CAXIAS DO SUL, 2010).

Entre as competências do Poder Executivo, descritas no artigo 2o da lei da Política Municipal do Meio Ambiente, destacamos três delas pelo seu papel fundamental. O inciso Io: "I promover medidas e estabelecer diretrizes de preservação, controle e recuperação do meio ambiente, considerando o como um patrimônio público, tendo em vista o uso coletivo e a melhoria da qualidade de vida", na qual as qualidades de vida da coletividade, através de um meio ambiente preservado, controlado e recuperado, são medidas a serem tomadas pelo Poder Público. É tratada no inciso VIo a prevenção e o combate à poluição: "VI prevenir e combater as diversas formas de poluição". E a proteção dos diversos patrimônios do município, como o patrimônio natural, histórico, estético entre outros: "VII proteger o patrimônio natural, histórico, estético, arqueológico, paleontológico, espeleológico e paisagístico do Município”.

A Lei Complementar 376/2010, por reunir toda a legislação ambiental do município, possui uma seção que dá um tratamento especifico à poluição visual, por meio dos artigos 54 ao 72. Essa lei compilada contém elementos que sintetizam um embasamento sólido para a criação da Lei Complementar no 412/2012.

Tratando-se do vínculo da melhoria na qualidade de vida com o meio ambiente, o Município de Caxias do Sul tratou o tema da poluição visual e do seu controle na Lei Complementar no 412, de 12 de junho de 2012. Sua regulamentação ocorreu através do Decreto no 16.834 de 27 de janeiro de 2014, sendo a Secretaria do Meio Ambiente a responsável pela implementação desta política de controle aos veículos de comunicação visual na cidade.

Os objetivos da Lei no 412/2012 são abordados neste estudo, sendo o controle da poluição visual o responsável pelo bem-estar estético, cultural e ambiental da população. Demonstra-se, desta forma, que o seu controle valoriza o ambiente natural e construído, e, portanto, preserva a memória cultural, nos moldes disciplinados no artigo 2으, inciso IIo, e alíneas "a", "c" e "f":

Art. 2o O Município disciplinará o uso dos veículos de divulgação, atendendo às seguintes finalidades:

$(\ldots)$

II. Elaborar e implantar normas para a construção e instalação desses veículos na cidade, objetivando:

a. O bem-estar estético, cultural e ambiental da população;

(...)

c. A valorização do ambiente natural e construído; 
$(\ldots)$

f. A preservação da memória cultural; (CAXIAS DO SUL, 2012).

O legislador caxiense, por intermédio da Lei Complementar no 412, de 12 de junho de 2012, busca disciplinar o uso dos veículos de divulgação no Município de Caxias do Sul, designado pelo poder executivo de Programa Visual Legal. A referida lei trata, com muita cautela, a veiculação publicitária que é tida não como um problema, mas o seu descontrole deve ser obstaculizado.

Em suas disposições preliminares, a lei trata da boa qualidade estética e do referencial paisagístico: "Art. 10 Todos têm direito à boa qualidade estética e referencial da paisagem do Município, sendo dever do Poder Público Municipal e da coletividade protegê-la e promovê-la para as atuais e futuras gerações" (CAXIAS DO SUL, 2012). [Grifo nosso].

Em nosso entendimento, por um lado, não houve abordagem inicial pelo legislador no que tange às consequências que a poluição visual traz à saúde do cidadão, sendo esta considerada por nós como o princípio norteador dessa lei. Por outro lado, no momento de sua aplicabilidade, o Programa Visual Legal, com seu regramento, consegue, de forma gradual, reordenar os veículos de divulgação no Município de Caxias do Sul e controlar a poluição visual.

Ainda, relacionando a normatização dos meios de divulgação, tanto da elaboração como da implantação com a norma, verifica-se que esta objetiva resultados em alguns pontos que são dignos de destaque, como o bem-estar estético, cultural e ambiental da população, sobressaindose, de forma qualificada, o tema da valorização do ambiente natural e construído, sendo este o mais importante elemento a ser observado na implementação desta legislação.

A partir da promulgação da Lei no 412/2012, toda alteração, substituição e instalação de novos veículos de divulgação na paisagem urbana necessita de autorização prévia do Município de Caxias do Sul, por meio da Secretaria Municipal do Meio Ambiente - SEMMA. O texto da lei isenta de autorização os anúncios indicativos com área de até $3 \mathrm{~m}^{2}$, que tem como consequência a isenção tanto de autorização, como de taxas, um número expressivo de estabelecimentos.

Os pedidos de autorização devem ser feitos através de requerimento próprio, no qual as exigências partem, desde a planta de situação e a localização do imóvel, o projeto arquitetônico, o responsável técnico pelo projeto e a execução, os materiais que o compõem, até a Certidão Negativa de Débito, o Alvará de Localização, entre outros.

O município analisa a referida documentação, e, caso preencha os requisitos, será expedida uma autorização válida por quatro anos. Após esse período, o requerente deverá necessariamente realizar um novo pedido, cumprindo os mesmos requisitos do pedido inicial. 
No que diz respeito aos meios de divulgação em edificações, a Lei № 412/2012 é bem clara quanto às limitações destes meios em suas fachadas, levando em conta o avanço de tais sinalizações, que estão proibidas de ultrapassar 30 centímetros do alinhamento da edificação. Desta forma, fica assegurado que tais veículos de comunicação não estarão fixados de forma perpendicular no passeio público. Observa-se, neste sentido, também a preocupação com a segurança na circulação de pessoas no passeio público, além da questão da poluição visual.

A Lei no 412/2012, em seu artigo $8^{\circ}$, parágrafo único, priorizando a circulação de pessoas em detrimento aos veículos de divulgação, proíbe, de forma expressa, a colocação de cavaletes no passeio público: “É proibida a colocação de cavaletes em vias e passeios públicos, bem como a utilização de propaganda, inclusive eleitoral, em postes de luz em todo o Município de Caxias do Sul" (CAXIAS DO SUL, 2012). [Grifo nosso].

Oportuno comentar ainda que, tanto em muros quanto em empena cega (CAXIAS DO SUL, 2012), a forma de utilização publicitária é realizada mediante pintura mural ou painel, afixado em estrutura própria e material rígido, sendo esta determinação mais um ponto positivo na segurança dos transeuntes.

Para uma melhor compreensão, versamos sobre como o Código de Trânsito Brasileiro, Lei no 9.503/1997 conceitua o termo passeio público, dividindo-o em duas partes, o de calçada e o de passeio:

CALÇADA - parte da via, normalmente segregada e em nível diferente, não destinada à circulação de veículos, reservada ao trânsito de pedestres e, quando possível, à implantação de mobiliário urbano, sinalização, vegetação e outros fins.

(...)

PASSEIO - parte da calçada ou da pista de rolamento, neste último caso, separada por pintura ou elemento físico separador, livre de interferências, destinada à circulação exclusiva de pedestres e, excepcionalmente, de ciclistas. (BRASIL, 1997).

Com a implementação da Lei Complementar no 412/2012, a memória cultural em edificações acaba sendo contemplada com o reaparecimento das fachadas dos prédios antigos, estando muitos destes esquecidos no tempo, com placas enormes, muitas vezes, cobrindo totalmente estas fachadas, agora retiradas e substituídas. Ao circularmos pela região central de Caxias do Sul, principalmente na área denominada "Centro Histórico", nos deparamos com as modificações das fachadas, em decorrência dessa LC, torna-se visível a importância de sua implementação. Neste contexto, são submetidos à análise da Comissão Específica e Permanente de Proteção ao Patrimônio Histórico e Cultural os projetos de veículos de divulgação, assim como os 
de recuperação das fachadas dos bens tombados e do seu entorno, as edificações inventariadas e o seu entorno, as edificações situadas em setores especiais, entre outras, sendo necessária a autorização dessa comissão.

Desta forma, a definição dada à paisagem urbana pelo legislador, para fins de aplicação da referida lei, qualifica os elementos naturais, como a água, a fauna e a flora, além de considerar os elementos construídos, tais como construções, edifícios, anteparos, superfícies aparentes de equipamentos de infraestrutura, de segurança e de veículos automotores, anúncios de qualquer natureza, elementos de sinalização urbana, equipamentos de informação e comodidade pública e logradouros públicos, visíveis por qualquer observador, situado em áreas de uso comum da população.

Depreende-se da leitura da Lei no 412/2012 que ela apresenta como pontos fortes a prevenção contra risco à segurança do trânsito ao proibir, nas vias públicas, qualquer publicidade não relacionada com a sinalização que gere confusão e interfira na visibilidade da sinalização de trânsito; preservação da memória e da cidade; e contribuição para a propiciar um ambiente satisfatório e atrativo, permitindo o desenvolvimento individual dos cidadãos. Como perspectivas futuras, verifica-se a necessidade de se intensificar a fiscalização e a conscientização da população através da educação ambiental.

A cada dia que passa, são constatadas alterações nas fachadas dos estabelecimentos comerciais, com o objetivo de se adequar à legislação municipal, desde a implantação do Programa Visual Legal, a Lei no 412/2012. Isso tem como consequência o aparecimento de uma sensação de bem-estar de forma gradual que está acompanhando as mudanças estéticas da cidade. Somente para ilustrar, Santos (2009), em sua Dissertação de mestrado faz uma pesquisa de campo no Centro tradicional de Salvador/BA, no qual verifica que utilizar elementos publicitários, sem rigor na fiscalização, transforma a paisagem em suporte para a exposição de cartazes, letreiros e outros, principalmente próximos a faixas de travessia e em vias de trânsito, causando insegurança e fazendo com que a atenção dos pedestres e motoristas seja dispersa, em muitos casos, causando acidentes. Por outro lado, Timba (2011), utilizando Sirvinskas (2008), afirma que chama mais a atenção a ausência de publicidade que o excesso dela, impedindo a visualização da beleza das construções antigas, como no caso da Cidade de Parati, na qual nas ruas, não existe publicidade. Isso instiga a curiosidade dos consumidores, que acabam entrando nas lojas para ver os produtos do comércio local. 


\section{ANÁLISE DO CASO CONCRETO DA LEI № $412 / 2012$}

A Lei Complementar 412 de 12 de junho de 2012, que disciplina o uso de veículos de divulgação no Município de Caxias do Sul, tem a sua aplicabilidade iniciada a partir da publicação do Decreto no 16.834, de 27 de janeiro de 2014.

Com a implementação da aludida legislação, de imediato, a prefeitura municipal, por intermédio da Secretaria Municipal do Meio Ambiente (SEMMA), inicia o trabalho de conscientização acerca da poluição visual para aos comerciantes, através de suas entidades, como a Câmara de Indústria e Comércio (CIC), o Clube de Diretores Lojistas (CDL), o Sindicato do Comércio Varejista de Caxias do Sul (Sindilojas), o Sindicato do Comércio Varejista de Gêneros Alimentícios de Caxias do Sul (Sindigêneros), entre outras.

A fiscalização foi iniciada em janeiro de 2014, e o setor responsável por ela é o SEMMA que iniciou uma força tarefa, em especial, no Setor Centro Histórico do Município ${ }^{10}$, Setor Especial (SE) do Plano Diretor, no procedimento de notificações aos estabelecimentos que estão em desacordo com a nova norma. Nessa primeira etapa, a Secretaria do Meio Ambiente notificou e garantiu aos comerciantes um prazo de 90 dias para a regularização de suas fachadas. Nos casos de inadequações, houve autuações e multas.

Entre 1 ㅇ de janeiro e 31 de março de 2014, mais de 800 notificações foram emitidas para comerciantes e prestadores de serviços pela Secretaria do Meio Ambiente. Aos que não estiverem em conformidade com a legislação, a autuação e a multa podem variar de 10 a 250 Valores de Referência Municipal (VRMs) ${ }^{11}$.

Segundo informação da SEMMA, o processo dura, em média, 45 dias e contempla estudo do projeto, pagamento da taxa e emissão do certificado. Assinala-se ainda que placas que estejam fixadas em marquises, imóveis tombados, inventariados e entornos do Setor Especial, Setor Especial Festa da Uva, Setor Especial Centro Histórico devem buscar autorização, independentemente, da metragem.

\footnotetext{
${ }^{10}$ Quadrilátero, formado pela Rua Alfredo Chaves até a Rua Moreira César e pela Rua Os 18 do Forte até a Rua Bento Gonçalves.

${ }^{11}$ Em 01/01/2015 - R\$26,56 = 1VRM - Município de Caxias do Sul.
} 


\section{Imagem Comparativa de Caso Concreto}

De forma gráfica, demonstraremos abaixo um comparativo entre os estabelecimentos que, aos poucos, vão se enquadrando na lei e iniciando um novo marco estético no Município de Caxias do Sul:

Dando início às alterações nas fachadas nos moldes da Lei Complementar no 412/2012, as edificações históricas da área central de Caxias do Sul ressurgem. As características arquitetônicas peculiares destacam-se, a partir da retirada dos materiais que as ocultavam. O passo seguinte é efetuar as adequações para atender o parecer emitido pela Comissão Específica e Permanente de Proteção ao Patrimônio Histórico e Cultural12.

Nas instalações das Lojas Bulla, por exemplo, situada na Avenida Júlio de Castilhos, no centro do município, onde estruturas metálicas e placas de propaganda cobriam a parte frontal da edificação (imagem 1), após a adaptação a Lei no 412/2012, com a retirada desses elementos de poluição visual, a sacada e a parte significativa da fachada, encoberta do prédio, retornam a ser visualizadas (Imagem 2).

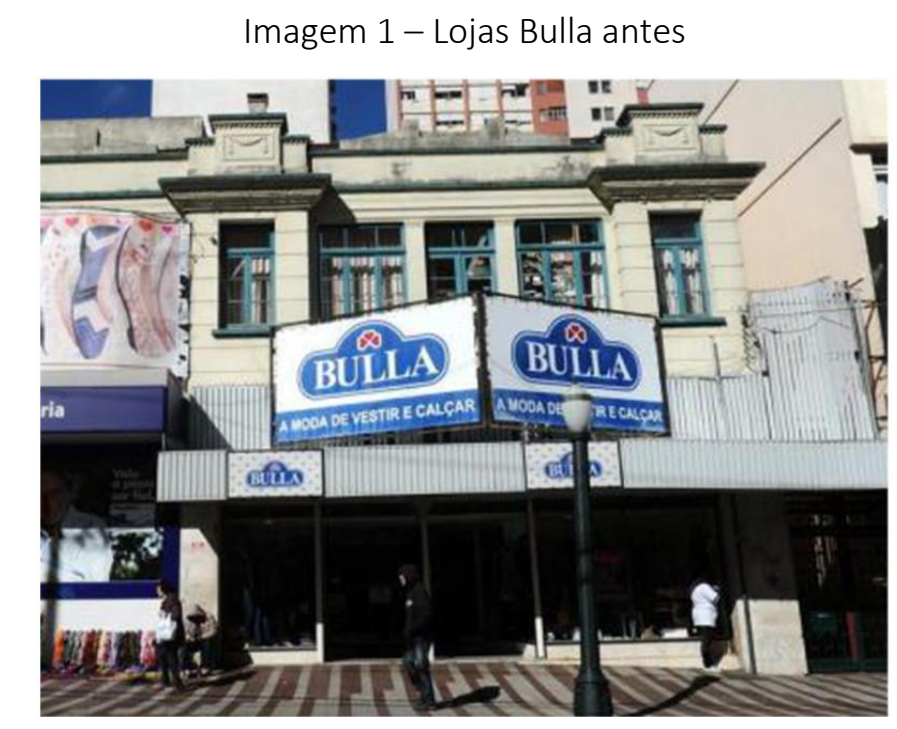

Fonte: Daniela Xu/Agência RBS

\footnotetext{
${ }^{12}$ Art. 70 Para efeito de análise dos pedidos de autorização, [...] as edificações situadas nos Setores Especiais (SE), constantes do art. 29, incisos I, II e V, [...]

Parágrafo único. O fornecimento da autorização mencionada no caput deverá ser precedido de análise por parte da Comissão Específica e Permanente de Proteção ao Patrimônio Histórico e Cultural (CAXIAS DO SUL, 2012).
} 
Imagem 2 - Lojas Bulla depois

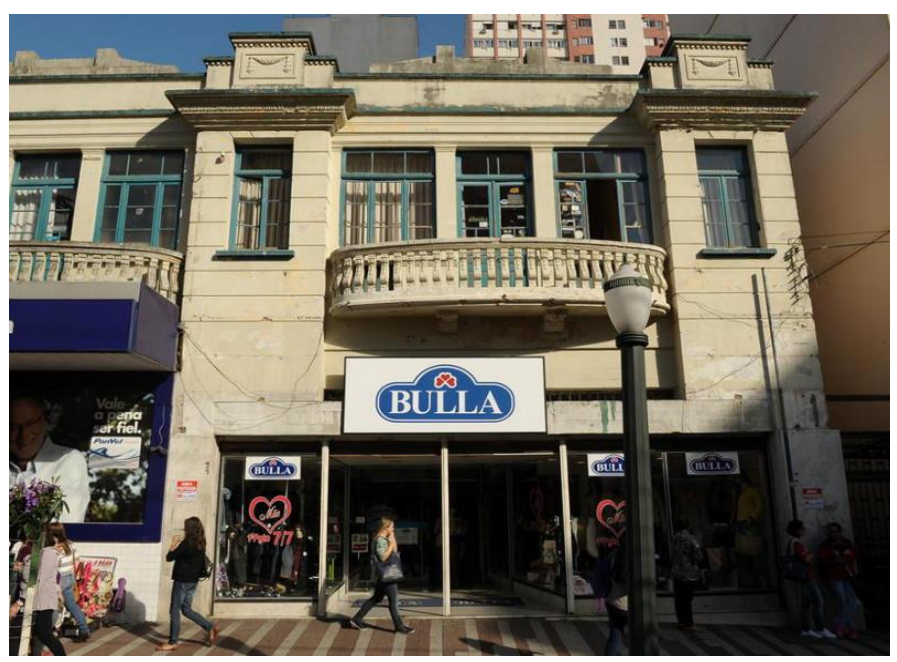

Fonte: Diogo Sallaberry/Agência RBS

Um prédio histórico, no coração da cidade, é o da Loja Magnabosco, construído há 74 anos, com toques de peculiaridade, conforme histórico da loja: "1939 - Inauguração do imponente prédio de alvenaria. O espaço passa a abrigar o empreendimento no térreo; o Fórum e a residência do juiz, no segundo andar; e o lar do proprietário, no terceiro piso".

Abaixo, faz-se um comparativo do prédio da Loja Magnabosco, em quatro situações. Inicialmente, em 1951 (Imagem 3), havia características arquitetônicas próprias desta época; e em 2010, antes do enquadramento à legislação (Imagem 4) como ela se apresenta neste período? 0 projeto arquitetônico foi apresentado para aprovação da Comissão Específica e Permanente de Proteção ao Patrimônio Histórico e Cultural e a Secretaria Municipal do Meio Ambiente (Imagem 5) e, atualmente, encontra-se com a execução do projeto (Imagem 6).

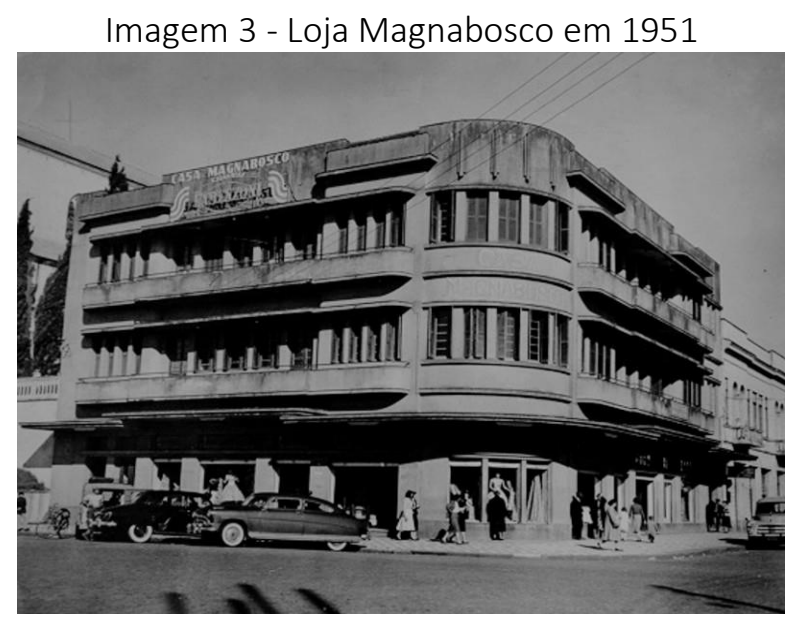

Fonte: acervo Loja Magnabosco 


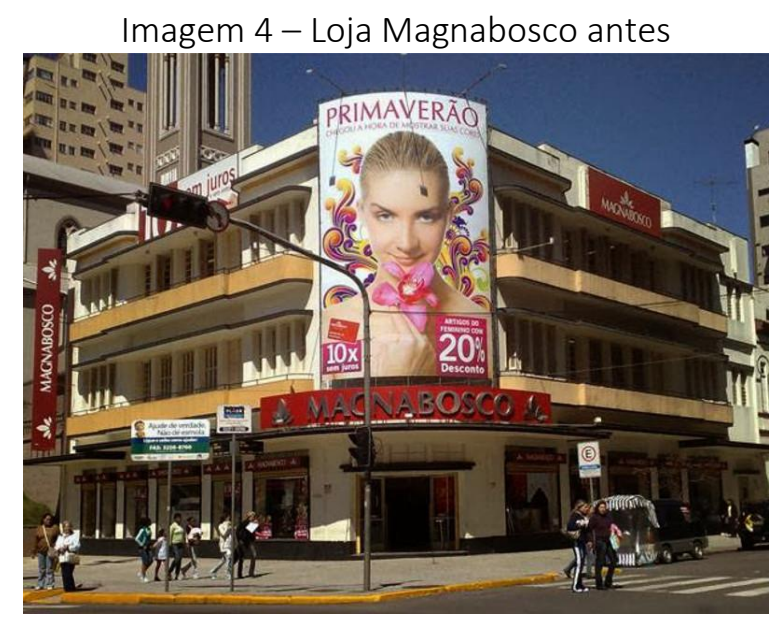

Fonte: acervo Loja Magnabosco

Durante décadas, os proprietários da Loja Magnabosco têm mantido as principais características da edificação histórica. Com a adequação à lei que disciplina o uso de veículos de divulgação no município, verifica-se, como resultado, nos dias atuais (Imagem 6), a recuperação das características originais do prédio (Imagem 3), demonstrando-se, assim, que a Lei Complementar no 412/2012 contempla não somente a poluição visual, mas também, de forma positiva, o resgate histórico-cultural.

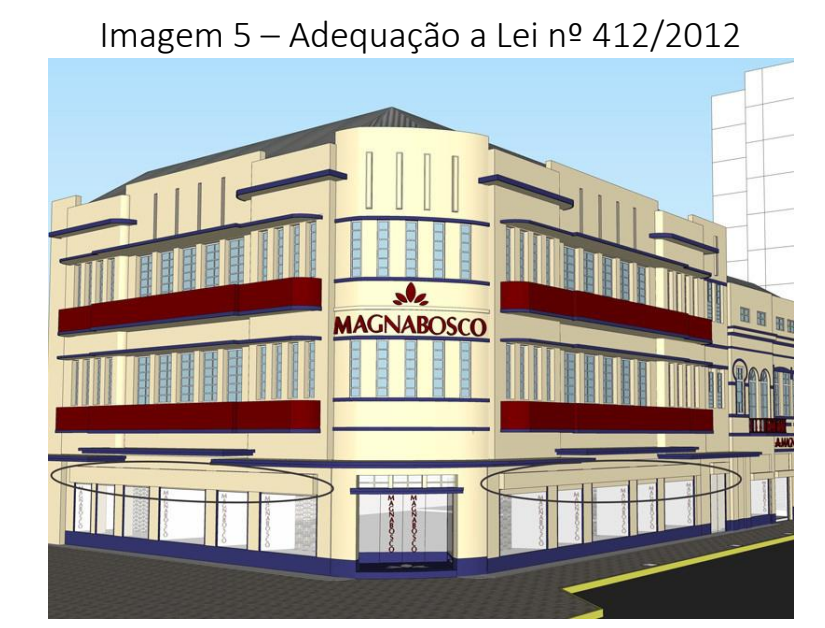

Fonte: Projeto Loja Magnabosco aprovado pelo Município 


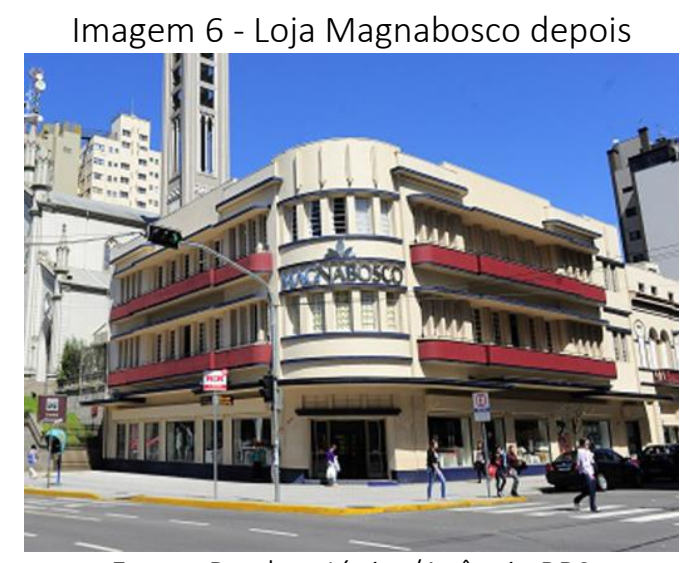

Fonte: Porthus Júnior/Agência RBS

As alterações ocorrem contínua e simultaneamente, visando ao bem-estar das pessoas que circulam pelo entorno destes pontos comerciais, e elas causam um grande impacto visual nos espaços.

A transformação tem sido feita de forma sistemática, e o resgate da história é consequência da implementação da lei. Elementos, removidos ou ocultos em edificações históricoculturais, agora recuperados ou ressurgidos, dão um toque nostálgico aos que conviveram em um passado não tão distante.

Observamos que a remoção da publicidade em excesso transforma o meio ambiente artificial urbano em um espaço público muito mais agradável para o convívio diário, como constatamos nas instalações da Lojas Colombo da Avenida Júlio de Castilhos, edificada em 1886 (Imagens 7, 8, 9 e 10). Sendo assim, a aparência externa deste estabelecimento comercial se torna um atrativo aos clientes.

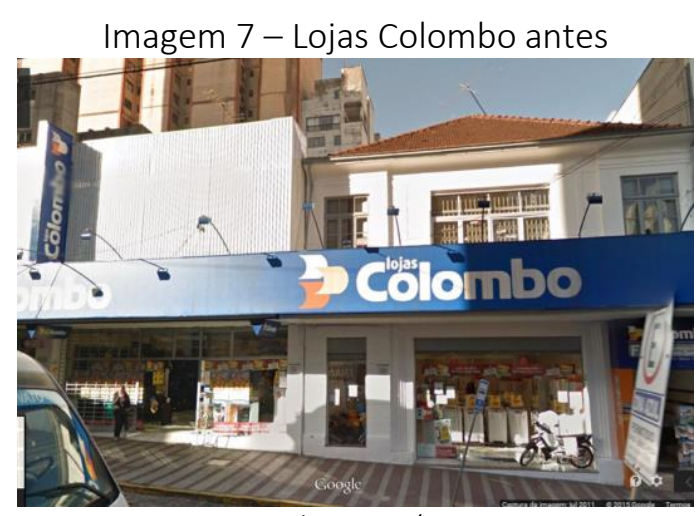

Fonte: Google Maps/Street View 


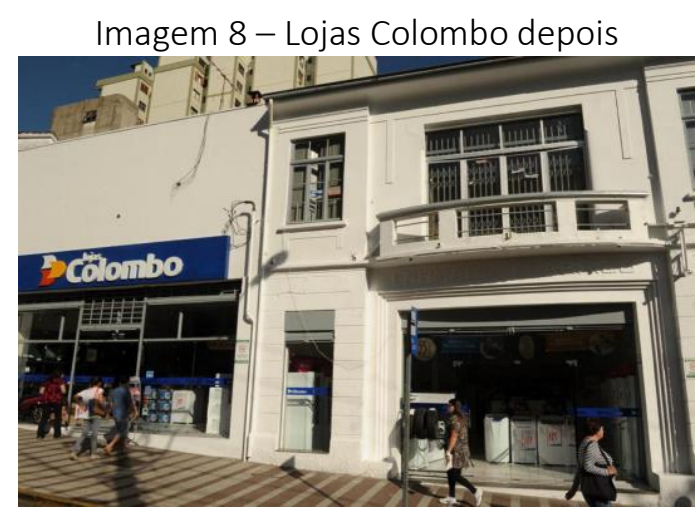

Fonte: Diogo Sallaberry/Agência RBS

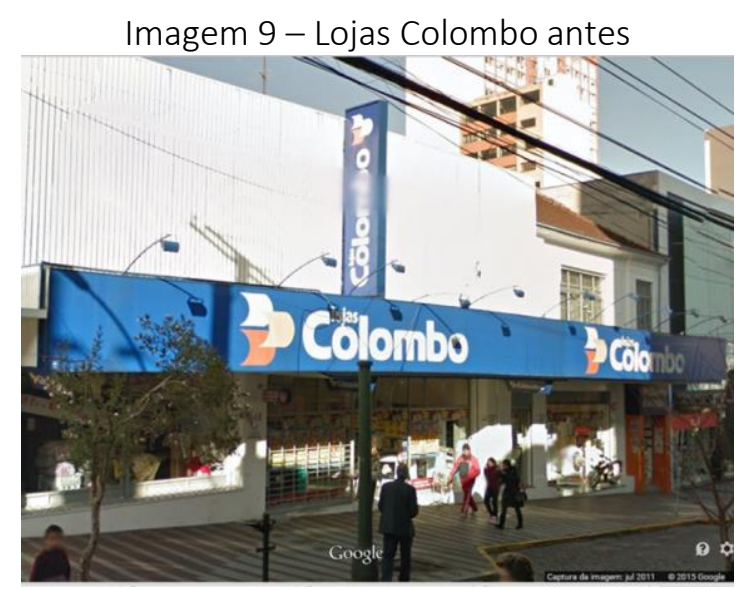

Fonte: Google Maps/Street View

Imagem 10 - Lojas Colombo depois

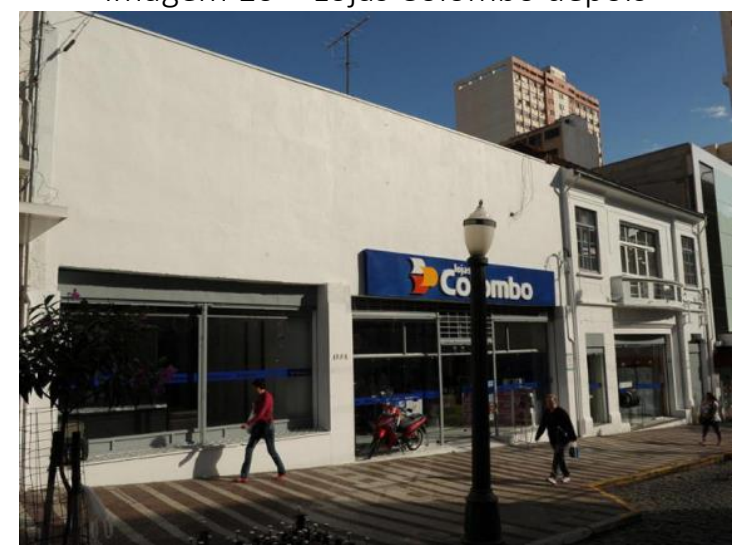

Fonte: Diogo Sallaberry/Agência RBS

As transformações das fachadas são visíveis e tornam o meio ambiente urbano mais harmonioso, contribuindo, efetivamente, para o bem-estar da população. Além disso, há um resgate cultural da história, principalmente, do centro da cidade, e os estabelecimentos tornam-se 
mais atrativos, concluindo-se, assim, sobre a importância da Lei no 412/2012 sob diversos aspectos.

\section{CONSIDERAÇÕES FINAIS}

A análise feita, através deste estudo quanto a poluição visual e o seu controle no Município de Caxias do Sul, segundo a implementação da Lei Municipal no 412/2012, demonstrou que o impacto, resultante desta lei de controle ambiental, é de percepção imediata.

No Brasil, a partir da Constituição Federal de 1988, através do caput do artigo 225, o meio ambiente é tratado como um "bem de uso comum do povo e essencial à sadia qualidade de vida", além da imposição ao "Poder Público e à coletividade o dever de defendê-lo e preservá-lo para as presentes e futuras gerações" (BRASIL, 1988). As legislações infraconstitucionais seguem no mesmo sentido de garantir que estes preceitos constitucionais sejam assegurados e cumpridos pela população e pelo Estado em todas as suas esferas. No entanto, de acordo com o que foi pesquisado, verificou-se a importância dada ao princípio da proteção desde a Conferência de Estocolmo (1972), mas que, com a justificativa de falta de comprovação científica, foi utilizado para impedir ou dificultar as ações de preservação do meio ambiente. Atualmente, o princípio limita-se a estabelecer que a falta de certeza científica não deve ser usada como meio de evitar a adoção de medidas preventivas, quando houver ameaça séria de dano irreversível. Infere-se, portanto, a resistência em por em prática medidas de proteção ao meio ambiente, e argumentar que ela servirá para as gerações futuras é uma forma de postergar a concretização dessas práticas.

Os municípios possuem a competência de legislar sobre temas ambientais de impacto local, cumprindo os requisitos das formas de cooperação da Lei Complementar 140/2011 (BRASIL, 2011), bem como a observância de suas competências constitucionais. Neste sentido, o Município de Caxias do Sul cumpre com o seu papel, trazendo para si a responsabilidade de assegurar a sadia qualidade de vida na questão da poluição visual, através da Lei no 412/2012. Do momento da publicação da Lei Municipal no 412/2012 até a entrada em vigor, na qual o prazo foi de 18 meses, o Poder Público promoveu ações, com o intuito de conscientizar, em especial, os comerciantes e os prestadores de serviço, ligados a associações de classe, quanto à necessidade de adequação à nova legislação. Os meios de comunicação locais também tiveram participação na divulgação da lei.

No que diz respeito à área central da cidade, a partir de janeiro de 2014, não é necessário questionar o resultado positivo da legislação, em que grande número de estabelecimentos já estão enquadrados na lei e tantos outros em fase de alterações em suas fachadas. Ao nos afastarmos do 
centro, percebe-se que, em novas instalações comerciais, o cumprimento à nova lei surte efeito, em parte pela liberação do alvará de localização pela prefeitura e, de por outra, através das orientações fornecidas pelos servidores do município. Mas, neste perímetro, o que mais se expressa são fachadas em desacordo com a Lei no 412/2012. O comerciante tende a efetuar as alterações em sua fachada irregular somente após receber notificação da fiscalização, e, desta forma, ou a prefeitura não está priorizando a fiscalização na periferia ou não possui quadro técnico suficiente para atender a demanda da nova lei. Isso evidencia que a política e o plano direto não possuem uma perspectiva de cidadania e do direito à cidade, onde a revitalização do centro histórico possui outros sentidos para além da "qualidade de vida".

Incompreensível também são os casos de reformas de fachadas, onde o comerciante refaz toda a estrutura externa de seu estabelecimento, com a instalação de letreiros novos, completamente em desacordo com a legislação. Seria esse comerciante desconhecedor da lei? A empresa prestadora de serviço de comunicação visual ${ }^{13}$ não Ihe informou que daquela forma seria irregular? Nessa hipótese, a lei deveria penalizar de forma mais severa os prestadores de serviço em comunicação visual que descumprirem a norma. No entanto, não podemos deixar de pensar a revitalização do centro histórico no contexto de uma cidade vista como mercadoria, uma vez que, nas cidades modernas há uma relação direta entre a organização espacial urbana e a (re) produção do capital. De acordo com Arantes (2012, p. 26) "as cidades passaram elas mesmas a ser geridas e consumidas como mercadorias". Há uma 'fabricação de consenso', explica Arantes (2012) relativo ao crescimento a qualquer preço, principalmente na questão econômica, que faz crer em uma 'chuva de empregos' como consequência do crescimento. Assim, com essa coalizão prócrescimento é possível visualizar o comportamento desse empreendedor (prestadora de serviços) como parte integrante de uma estratégia de crescimento a todo custo.

A ambição de obter lucro é outro elemento que, aliado à deficiência na fiscalização, faz com que vários comerciantes transformem suas fachadas em vitrines estampadas de publicidade irregular. A participação da sociedade, por conseguinte, é fundamental nestes casos, através de

${ }^{13}$ Segundo o artigo 6o da Lei Complementar no 412/2012, os fabricantes de veículos de divulgação necessitam de cadastro e autorização da Prefeitura Municipal e a não observância da fabricação e instalação dos veículos de divulgação estão igualmente sujeitos às penalidades:

Art. $6^{\circ} \mathrm{A}$ exploração ou utilização dos veículos de divulgação presentes na paisagem urbana e visíveis dos logradouros públicos será promovida por pessoas físicas ou jurídicas que industrializem, fabriquem ou comercializem veículos de divulgação ou seus espaços, desde que devidamente cadastradas e autorizadas pelo Município. [grifo nosso].

Revista de Direito da Cidade, vol. 07, no 4. Número Especial. ISSN 2317-7721 pp.1708-1749 1745 
denúncias à prefeitura, auxiliando o Poder Público na inibição de tais excessos e na completa implementação da legislação.

Não obstante aos resultados obtidos pela neutralização da poluição visual, a referida lei traz como resultado o resgate do patrimônio histórico-cultural, tornando-o visível e em processo de revitalização. Desta forma, concluímos, nesta pesquisa, que a Lei no 412/2012 transforma o ambiente poluído visualmente em um espaço mais agradável e harmônico. Os resultados obtidos são mais céleres na região central da cidade, pela presença contínua da fiscalização. Quanto aos bairros mais afastados, a implementação é mais lenta, e o seu controle se torna mais difícil pelo poder público. Diante desta constatação, questiona-se por que esta lei não é cumprida igualmente em todo o município pelo poder público? Em um primeiro momento, poderia concluir-se pela falta de efetivos para a ampla fiscalização, contudo, existindo a possibilidade de iniciar essas ações pelos bairros mais afastados, verifica-se que é uma questão de prioridade. Provavelmente por uma questão de interesse econômico e de priorizar os comerciantes em detrimento dos bairros residenciais é que se optou por iniciar a fiscalização pelo centro da cidade.

Ações, nos moldes da Lei no 412/2012, repercutem positivamente, isentando o ambiente visual da poluição. A implementação de legislações ambientais nesta direção é importante para a melhoria da qualidade de vida no meio urbano. Os municípios brasileiros, habilitados a conferir o licenciamento ambiental municipal, por meio de sua capacidade de legislar sobre o tema, possuem uma grande oportunidade de implementar leis de controle da poluição visual.

É necessário registrar que, inicialmente, este estudo possuía uma abordagem direcionada à poluição visual, sendo constatado, no decorrer desta análise, a influência e a importância da lei no resgate histórico-cultural, no qual o Conselho Municipal do Patrimônio Histórico e Cultural (COMPAHC), por intermédio da Comissão Específica e Permanente, possui um papel fundamental na análise de projetos de adequação a Lei no 412/2012, pela sua cautela e critérios técnicos no momento de sua aprovação.

\section{REFERÊNCIAS}

ALVES, José Eustáquio Diniz. A Polêmica Malthus versus Condorcet reavaliada à luz da transição demográfica. Rio de Janeiro: Escola Nacional de Ciências Estatísticas, 2002.

ANTUNES. Paulo Bessa. Direito Ambiental. 10. ed. atual. Rio de Janeiro: Lumen Juris, 2007.

BAUDRILLARD, Jean. Para uma crítica da economia política do signo. Lisboa: Edições 70. [1972] 1995.

Revista de Direito da Cidade, vol. 07, no 4. Número Especial. ISSN 2317-7721 pp.1708-1749 1746 
BEHRENDS, Laura Romeu. O movimento ambientalista como fonte material do direito ambiental [recurso eletrônico]. Porto Alegre: EDIPUCRS, 2011.

BERNARDI, Jorge. A organização municipal e a política urbana. São Paulo. Intersaberes, 2012.

BRASIL. Constituição (1967). Constituição [da] República Federativa do Brasil. http://www.planalto.gov.br/ccivil_03/Constituicao/Constituicao67EMC69.htm. Acesso em 09 nov. 2014.

Constituição (1988). Constituição [da] República Federativa do Brasil. Brasília, DF: Senado Federal.

Decreto no 5.790/06. Dispõe sobre a composição, estruturação, competências e funcionamento do Conselho das Cidades - ConCidades. Disponível em http://www.planalto.gov.br/ccivil_03/_ato2004-2006/2006/Decreto/D5790.htm. Acesso em 26 abr. 2015.

Lei no 6.938/81. Política Nacional do Meio Ambiente. http://www.planalto.gov.br/ccivil_03/leis/l6938.htm. Acesso em 09 nov. 2014.

Lei no 7.347/85. Disciplina a ação civil pública de responsabilidade por danos causados ao meio-ambiente. Disponível em http://www.planalto.gov.br/ccivil_03/leis/17347orig.htm. Acesso em 19 nov. 2014.

Lei no 9.503/97. Código de Trânsito Brasileiro. Disponível em http://www.planalto.gov.br/ccivil_03/leis/I9503.htm. Acesso em 15 nov. 2014.

Lei $\mathrm{n}$ - 9.605/98. Dispõe sobre as sanções penais e administrativas derivadas de condutas e atividades lesivas ao meio ambiente. Disponível em http://www.planalto.gov.br/ccivil_03/leis//9605.htm. Acesso em: 19 nov. 2014.

Lei no 10.257/01. Estatuto da Cidade: que estabelece diretrizes gerais da política urbana. Disponível em http://www.planalto.gov.br/ccivil_03/leis/leis_2001/l10257.htm. Acesso em 09 nov. 2014.

Lei no 10.683/03. Dispõe sobre a organização da Presidência da República e dos Ministérios. Disponível em http://www.planalto.gov.br/ccivil_03/leis/2003/l10.683.htm. Acesso em 26 abr. 2015.

Lei Complementar no 140/11. Dispõe sobre a cooperação entre a União, os Estados, o Distrito Federal e os Municípios nas ações de proteção do meio ambiente. Disponível em http://www.planalto.gov.br/ccivll_03/LEIS/LCP/Lcp140.htm. Acesso em 23 mai. 2015.

BRASIL. Medida Provisória no 2.220/01. Cria o Conselho Nacional de

Desenvolvimento Urbano - CNDU. Disponível em http://www.planalto.gov.br/ccivil_03/mpv/2220.htm. Acesso em 26 abr. 2015.

Resolução CONAMA: no 1, de 23 de janeiro de 1986 que dispõe sobre critérios básicos e diretrizes gerais para a avaliação de impacto ambiental. Publicada no DOU, de 17 de fevereiro de 1986, Seção 1, p. 2548-2549.

Resolução CONCIDADE: no 34, de 01 de julho de 2005 que dispõe sobre a emissão de orientações e recomendações quanto ao conteúdo mínimo do Plano Diretor. Publicada no DOU, de 14 de julho de 2005, Seção 1, p. 89.

CASTANHEIRO, Ivan Carneiro. A poluição visual: formas de enfrentamento pelas cidades.Revista Internacional de Direito e Cidadania, n. 4, Erechim, Habilis, 2009, p. 63-78. 
CAXIAS DO SUL. Lei Complementar no 290/07 institui o Plano Diretor no Município de Caxias do Sul Jornal do Município, Data de Publicação: 24/09/2007.

Lei Complementar no 412/12 que disciplina o uso de veículos de divulgação no Município de Caxias do Sul. Jornal do Município, Data de Publicação: 30/06/2012.

Lei Ordinária no 2087/72 que institui o Plano Diretor no Município de Caxias do Sul. Data de Publicação: 27/12/1972.

Lei Complementar no 376/10 que consolida a legislação relativa à Política Municipal do Meio Ambiente. Disponível em http://www.camaracaxias.rs.gov.br/Leis/LC/LC-00376.pdf. Acesso em 02 ago. 2015.

Lei Orgânica do Município de Caxias do Sul. Promulgada em 04/04/1990.

Regularização da Lei de Comunicação Visual inicia nesta terça-feira. Disponível em: https://www.caxias.rs.gov.br/meio_ambiente/noticias_ler.php?codigo=27710. Acesso em 23 mai. 2014.

SEMMA inicia notificação do descumprimento da lei da Comunicação Visual. Disponível em: https://www.caxias.rs.gov.br/meio_ambiente/noticias_ler.php?codigo=26802. Acesso em 23 mai. 2014. mai. 2014.

Site da Loja Magnabosco. Disponível em: http://magnabosco.com.br/historia. Acesso em: 23

CENEVIVA, Walter. Direito constitucional brasileiro. São Paulo: Saraiva, 2003.

DANTAS, Ivan Coelho, SILVA, José Ednaldo Feitoza da. Poluição visual: que mal isso faz? Biofar: Revista de Biologia e Farmácia. Número 2- Volume 2 - 2008.2 http://sites.uepb.edu.br/biofar/download/v2n2-2008/06-poluicao_visual.pdf - Acesso em 01 mai. 2015,p. 50-62.

DEMAJOROVIC, Jacques. Sociedade de risco e responsabilidade socioambiental: perspectivas para a educação corporativa. São Paulo: Ed. Senac, 2003.

FIORILLO, Celso Antonio Pacheco. Curso de direito ambiental brasileiro. 12. ed. rev., atual. e ampl. São Paulo: Saraiva, 2011.

KARSAKLIAN, Eliane. Comportamento do consumidor. 2. ed., 6. reimpr. São Paulo: Atlas, 2012.

MEIRELLES, Hely Lopes. Direito de construir. 3. ed. refundida. São Paulo: Ed. Revista dos Tribunais, 1979.

MINC, Carlos. Ecologia e cidadania. 2a ed. São Paulo: Moderna, [1998] 2005. (Coleção polêmica).

MUKAI, Toshio. Temas atuais de direito urbanístico e ambiental. Belo Horizonte: Fórum, 2004.

SANTOS, Alfredo Nascimento. Interferência da poluição visual na percepção do centro tradicional da Cidade de Salvador. Orientador: Profa. Dra. Ilce Marilia Dantas Pinto de Freitas Dissertação (mestrado) - Universidade Federal da Bahia. Escola Politécnica, 2009.

SÃO PAULO. Decreto no 47.950/06 que dispõe sobre a ordenação dos elementos que compõem a paisagem urbana do Município de São Paulo. Disponível em 
http://www3.prefeitura.sp.gov.br/cadlem/secretarias/negocios_juridicos/cadlem/integra.asp?alt=0 6122006D\%20479500000. Acesso em 02 ago. 2015.

SIRVINSKAS, Luís Paulo. Manual de direito ambiental. 11. ed. São Paulo: Saraiva, 2013.

TIMBO, Maria Santa Martins. O direito a um meio ambiente artificial sem poluição visual. Direito Público, vol. 1, n. 39. Brasília: Síntese, 2011, p. 232-241.

VASCONCELLOS, Esdra Guerreiro. Stress, saúde e poluição visual. Instituto Paulista de Stress, Psicossomática e Psiconeuroimunologia (IPSPP), São Paulo, 2003.

WESCHENFELDER, Paulo Natalicio. Do direito constitucional ao meio ambiente equilibrado: a construção de uma cultura. Caxias do Sul: EDUCS, 2012.

Trabalho enviado em 28 de agosto de 2015.

Aceito em 07 de novembro de 2015. 